\title{
Modern energy consumption and economic modernisation in Latin America and the Caribbean between 1890 and $1925^{*}$
}

\author{
M.d.Mar RUBIO, Universitat Pompeu Fabra \\ César YÁÑEZ, Universitat de Barcelona \\ Mauricio FOLCHI, Universitat Pompeu Fabra and Universidad de Chile \\ Albert CARRERAS, Universitat Pompeu Fabra
}

\begin{abstract}
In the absence of comparable macroeconomic indicators for most of the Latin American economies before the 1930s, the apparent consumption of energy is used in this paper as a proxy of the degree of modernisation of Latin America and the Caribbean. This paper presents an estimate of the apparent consumption per head of modern energies (coal, petroleum and hydroelectricity) for 30 countries of Latin American and the Caribbean for 1890 to 1925 , multiplying the number of countries for which energy consumption estimates were previously available. As a result, the paper provides the basis for a quantitative comparative analysis of modernisation performance beyond the few countries for which historical national accounts are available in Latin America.
\end{abstract}

Keywords: Energy consumption, economic modernisation, Latin America

JEL codes: N160, N760, Q430, O130

\footnotetext{
* This article is the result of a research project entitled 'Imports and economic modernization in Latin America 1890-1960', financed by the Spanish Ministry of Education (Project No: BEC2003-00190). We are obliged to the rest of the team members for their encouragement and help: X.Tafunell and A.Hofman. Earlier drafts have also benefited from the comments of S.Kuntz, G.Marquez, C. Sudria, and the participants of the following meetings and conferences: Economic History Society Conference (Leicester), Canadian Network of Economic History meeting (Queen's University), the Cliometric's Conference (Binghamton), the International Economic History Society Conference (Helsinki), the Economic History Association Meeting (Pittsburgh), and the LACEA Conference (Mexico). The authors gratefully acknowledge the research assistantship of J. Jofré, F. Notten and C. Román.
} 


\section{Modern energy consumption and economic modernisation in Latin America and the Caribbean between 1890 and 1925}

In the interpretation of the process of economic modernisation of the last two centuries, it is widely accepted that the productivity gains achieved through the development of new energy carriers (from wood to coal and later to petroleum and electricity) play an important role. From this viewpoint, the Industrial Revolution has been interpreted as the 'process that allowed the exploitation at great scale of new energy sources by means of inanimate converters ${ }^{11}$ and it has been argued that coal - and later oil- was 'a strategic item in the rise and diffusion of the industrial civilisation'. ${ }^{2}$

It is within this context that it has also been claimed that 'economic history makes it evident that the industrial standing of any country may be gauged, with a fair degree of accuracy, from its development of mechanical power'. ${ }^{3}$ Of the 33 countries that constitute Latin America and the Caribbean at present, we have series of comparable historical national accounts for a handful of them. ${ }^{4}$ Consequently, the comparative analysis of the economic performance of the region as a whole has been constrained to the countries for which historical economic indicators have been constructed. The earlier the period we consider, the more constrained the sample becomes. The issue of the lack of quantitative evidence does not only affect the comparative economic history of the region as a whole. The lack of quantitative substantiation is particularly troublesome for the individual economic histories of the smaller countries. For these, very little is known about their economic performance over the very long run.

In the absence of comparable macroeconomic indicators for most of the Latin American economies before the 1930s, we take the apparent consumption of energy as a proxy of the degree of modernisation of Latin America and the Caribbean. ${ }^{5}$ For this purpose this paper presents an estimate of the apparent consumption per head of coal, petroleum and hydroelectricity for 30 countries and colonial territories of Latin America and the Caribbean for the period 1890-1925. To construct our estimates, we use the foreign trade statistics of the 
principal trade partners of Latin American and Caribbean countries and territories, plus data on home production of coal, petroleum and hydroelectricity. From a conceptual standpoint, we argue that the apparent consumption of modern energies - which in the period 1890-1925 correspond to mineral coal, petroleum and the first steeps of hydroelectricity - makes evident the pace at which the most modern activities evolve within a country.

Therefore, this research achieves, for the first time, a comparative homogeneous indicator of economic progress for the whole of the region. This is an evident breakthrough in the economic history of Latin America and the Caribbean. Until this very moment, similar coverage was only possible from 1945 thanks to the GDP figures of the United Nations prepared by the ECLA. Previous statistical compilations, such as Maddison (2001), Thorp (1998) or Bulmer-Thomas (2003), offer numerous series of a wide range of indicators, but none covering the entire region with a homogeneous indicator on annual basis as we do here.

The paper contributes to several literatures. On the one hand, it offers a comparison of the foreign trade statistics of the Latin American countries with that of the advanced economies (United Kingdom, United States and Germany), showing that the former are far more reliable than previously thought in the literature. On the other hand, the paper adds to the environmental and energy history studies by multiplying the number of countries for which energy consumption estimates were previously available in Latin America. Last but not least, the paper contributes to the wider economic history debate in Latin America providing the basis for a comparative analysis of modernisation performance, beyond the countries for which historical national accounts are currently available.

The paper is organised as follows. Section I furnishes the basis of our approach. The relationship between fossil energy consumption and economic modernisation is a long-standing proposal in economic history literature, more recently entering models of economic theory and applied economics. In Section II, the existing works that elaborated historical estimates of energy consumption in Latin America are surveyed and scrutinised. Before starting to analyze the annual series, and with the purpose to firmly establish the reliability of the data used, we present a comparison of foreign trade data of the Latin American countries and their main 
partners in 1925 for coal and oil. In so doing, we make fully explicit the foundations of our estimates. Thus, the methodological considerations regarding the construction of the series of apparent consumption of fossil fuels are presented in Section III. In Section IV we present the patterns of modern energy consumption in Latin America and the Caribbean, including the figures of the 30 annual series that we have estimated. The data on energy consumption is then used in Section V to propose a new periodization of the main phases of Latin American economic modernization between 1890 and 1925. We recapitulate and conclude in Section VI.

The importance of modern energy sources for the economic growth which commenced with the Industrial Revolution did not escape contemporary witnesses. Among them, the British economist William Stanley Jevons has a prominent position. In his seminal work, he asserted 'coal, in truth, stands not beside but entirely above all other commodities. It is the material energy of the country - the universal aid - the factor in everything we do. With coal almost any feat is possible or easy; without it we are thrown back in the laborious poverty of early times. ${ }^{, 6}$ Academics and non-academics recognised from the start the crucial role the new form of energy was to play in their daily life as much as in the progress of the nation. Just a year after of Jevons' publication, The Times insisted: 'Coal is everything to us. Without coal, our factories will become idle, our foundries and workshops be still as the grave; the locomotive will rue in the shed, and the rail be buried in the weeds. Our street will be dark, our houses uninhabitable'. ${ }^{7}$ It was clear; the comfort of modern life was intrinsically tied to coal.

At the advent of the new century, the qualitative relationship between energy use and wealth was amply discussed and widely accepted by economists. ${ }^{8}$ Nevertheless, it was not until the works of T. Read that an attempt was made to establish a quantitative relationship. ${ }^{9}$ With his estimates of energy consumption ('world's work output', as he called it) for 30 countries in 1929 he concluded that 'a general relationship between work done per capita and economic well-being is observable; but a precise correlation is not yet possible' ${ }^{10}$ Of course, the correlation between 
welfare and energy per capita was difficult to find back then, since no standard procedure for the valuation of national income was yet available.

Almost simultaneously, in 1934, Lewis Mumford published a book that reviewed history from an energetic viewpoint for the first time: Technics and Civilisation. ${ }^{11}$ Following the ideas of Patrick Geddes, Mumford proposed that industry had in fact been developing steadily over the last millennium. He broke this down into three overlapping phases, characterised by a specific mix of power and materials. Thus the 'eotechnic' phase (1000-1750) was defined by water-andwood; the 'paleotechnic' phase (1700-1900) was coal-and-iron based, and the 'neotechnic' phase (1850 onwards) was characterised by an electricity-and-alloy complex. ${ }^{12}$ In his view, history could be interpreted in terms of successive episodes of 'energy releases'. Each of them would provide more energy for society, an improvement in the supply regularity, more flexibility in the distribution, and a more efficient use. Economic historians such as C.Cipolla and E.A.Wrigley would reformulate some of these ideas, regarding the importance of energy to modern economic development, some 30 years later.

In his Economic History of World Population, C. Cipolla proposed a view of human history based upon energy consumption. ${ }^{13}$ The history of humankind could be divided into three stages split by two revolutions. The first one, the Neolithic revolution, started around 10,000 years ago when hunter-gatherers settled in small communities and learned to produce their own food, sowing cereal grains and breeding better plants. In energetic terms, this implied a process by which 'humans controlled and increased the array of biological converters' (plants and animals). ${ }^{14}$ The second energetic revolution would be what we all refer to as the Industrial Revolution. In words of C. Cipolla, it was the 'process that allowed the exploitation at great scale of new energy sources by means of inanimate converters' ${ }^{15}$ With the introduction of new energy sources, the Industrial Revolution changed dramatically the energy budget of human societies. Agricultural societies dispose of a very limited energy supply, mostly from an organic base. Industrial societies have at their disposal greater energy possibilities, chiefly form inanimate sources. 
The historical significance of these changes, especially from the development of the steam engine, is that humanity progressively obtained higher levels of disposable energy per head. Part of this translated only into more energy consumption per capita (heating, lighting, transports, etc) but also into more energy per labourer, and consequently, greater labour productivity. ${ }^{16}$ As a result of these, industrial societies entered into a new cycle of economic growth, which at the same time, acted as a stimulus for the development of new energy forms: 'the more energy produced, the more energy was sought out' ${ }^{17}$ The increase of available energy to industrial society and its effect on productivity, implied the expansion of real income per capita, improved welfare levels, and the satisfaction of needs well above the purely basic ones. In summary 'due to the exploitation of the new forms of energy, the greater abundance of capital, and a more efficient use of production factors, real income is greater in industrial societies than in agricultural societies' ${ }^{18}$

The very same year of the publication of Cipolla's book, another prominent economic historian, E.A.Wrigley, published an article entitled 'The supply of raw materials in the Industrial Revolution'. ${ }^{19}$ In it he started to delineate a thesis, very close to the ideas of C.Cipolla, which years later would be published in the form of the book Continuity, chance and change: the character of the Industrial Revolution in England. ${ }^{20}$ Almost simultaneously with the publication of this book, downward revisions of the growth rates of the classic period of the Industrial Revolution started to appear. ${ }^{21}$ Unlike Cipolla, Wrigley had the time to include them in his later assessments. Nevertheless, a 'slower' Industrial Revolution did not move him an inch from his main line of argument. ${ }^{22}$ According to Wrigley, what was extraordinary about the rate of growth of product per head in England in the century between 1750 and 1850 was not that it was so low but that it did not turn negative. Given the rate of population growth over the period, output per head and depressed living standards were to be expected. To escape from this danger, to avoid the growth curve becoming asymptotic, it was essential to break free from the constraint imposed by the energy budgets of organic economies, which depended almost exclusively upon annexing as much as possible of the annual inflow of solar energy from plants, humans and animals. Such economies were incapable of sustaining growth over a prolonged 
period since the maximum quantity of heat and mechanical energy, which could be secured in this fashion, was modest. Escape was possible because a succession of technical innovations meant coal could be used in a widening range of applications where heat energy was needed, and at a later stage, because of the ingenuity and perseverance of men such as Newcomen and Watt, the burning of coal could be used to overcome bottlenecks in the use of mechanical energy also. The significance of the gradual circumvention of the energy bottleneck was not that it produced a sudden acceleration in the rate of the growth of the economy or in the level of individual productivity. It was that it removed a barrier, which would otherwise have tended slowly to constrict growth. Only at a much later stage in the process by which the organic economy gave way to a mineral-based energy-intensive economy did the full benefit emerge in the form of a significantly higher rate of economic growth both in aggregate and per head.

Most economic historians accept the crucial role played by modern energy sources, especially fossil fuels, in the process of economic development along the lines just described. In fact, primary energy consumption per capita has been signalled as a proximate and measurable determinant of growth in historical exercises. ${ }^{23}$ Thus economic history literature endorses, in the main, our approach of using fossil energy consumption as a proxy of the degree of economic modernisation of a group of countries in absence of more explicit macroeconomic indicators. Yet, we must also seek out support from the economic literature, in the form of theoretical and applied studies.

Economic literature tended to focus on how energy demand is driven by economic development, and/or how a potential energy shortage may strangle economic growth, rather than how energy contributes to economic development. ${ }^{24}$ Nevertheless, support can also be drawn from theoretical and applied economic literature where the focus tends to be on how energy demand is driven by economic development, and/or how a potential energy shortage may strangle economic growth. ${ }^{25}$ On the empirical side, numerous studies aim at providing evidence about whether the level of energy inputs thrusts economic growth or whether it is the output level what governs the energy input. ${ }^{26}$ According to the latest results the relationship between energy availability and output levels seems to be quite strong. ${ }^{27}$ Multivariate tests demonstrate 
that the level of energy use is significant for explaining the level of output. ${ }^{28}$ The relevant fact for our purposes is that the overall positive correlation between economic growth and energy growth remains one of the most important stylized facts we can draw from history, even if the extent of this correlation and its patterns over time are highly variable. ${ }^{29}$

Furthermore, the correlation between economic output and energy consumption is strong and positive, but not all forms of energy have the same impact on economic output. Remaining trapped in traditional/organic forms of energy seems to have a negative correlation with the level of development attained by any one country. The explanation probably lies with the original thought of Wrigley in relation to the limits of the organic economy. Evidence of the positive correlation of modern forms of energy with economic output but negative correlation for traditional forms of energy and output for Latin America is shown in Figures 1 and 2.

[FIGURE 1: Modern energy per capita (coal, oil \& hydroelectricity) vs GDP per capita in Latin American countries, 1937]

\section{[FIGURE 2: Ratio of organic energy consumption on total energy consumption and GDP per capita for Latin American countries, 1937]}

These results, together with the economic history tradition, incline us to consider that our work is built on solid ground. In the absence of better economic indicators, modern energy use is a valid guide to determining the modernisation level of various countries at a given point in time. Those activities making use of the brand new technologies of the late $19^{\text {th }}$ century and the dawn of the $20^{\text {th }}$ were, with all probability, users of coal, petroleum and/or electricity.

The use of modern energies brought about increases in efficiency and productivity in most sectors of the economy, but especially in industry and transports, without forgetting the widespread diffusion of new ways of lighting in any modern city and home. Comparing a wide collection of countries through their apparent consumption of modern energies reveals, more than anything else, the relative degree of economic activity above the subsistence level.

Although energy consumption is an aggregated indicator of economic activity, it should not be used as direct substitute of major economic indicators as income and product. Precisely 
because it does focus on the modern sectors of the economy, energy consumption may exaggerate the relative differences across countries. Our indicator tends to push upwards industrial, mining, commercial and/or urban countries and push downwards predominantly agrarian and/or rural economies Yet, in absence of sufficient data for the reconstruction of the national accounts, the apparent consumption of modern energy offers a good proxy for the trends and evolution of economic prosperity.

II

Ours is not the first attempt to reconstruct the apparent consumption of energy in Latin America in historical terms. Other studies have provided point estimates and some historical series of energy consumption in Latin America are available. Most of them, however, start in the post-war period and provide data for a limited number of countries. In fact, energy studies were relatively scarce before the energy crisis of the 1970s. The concerns about energy scarcity raised then also affected Latin America. Some of the resulting reports are reviewed here, yet they did not attempt any kind of historical reconstruction of the data.

The first monograph about energy in Latin America we are aware of, is a report by the United States Department of Commerce published in 1931. The report sets out from the idea that the use of coal, petroleum, and water 'is an index of industrial attainment, and that their availability in a country will strongly affect that country's future position, ${ }^{30}$ The objective of the report was not academic, but to explore the double role of Latin America as supplier of raw materials and growing market for the United States products. Nevertheless, the report offers an appealing review of the energy availability for a long list of countries, although extremely unequal in coverage and detail. ${ }^{31}$ In some cases information does not go beyond stating the existence or absence of national production of coal and petroleum. For most countries, patchy data on imports, industrial consumption and prices of coal and oil, electric installed capacity, and existence of public utilities (railways, tramways, etc) are provided, mostly for the second half of the 1920s. A punctual estimate of the coal and fuel-oil consumption and potential and developed waterpower for 18 countries is given for the year $1928 .{ }^{32}$ Although informative for United States 
merchants, the disparity of data used, particularly those relating to coal and water, make the final estimates across countries, as it is recognised in the first page of the report.

Another punctual estimate of energy consumption for Latin American countries was the one by Read already mentioned. His earlier calculations were predominantly for the United States and were mostly based on data for 1924-25. He later included a larger number of countries from all over the world ( 30 in total), and used the latest figures available that were quantitatively the largest (usually 1929). ${ }^{33}$ His results may therefore be roughly taken as representing the highwater mark. Read's estimates of 'daily output of work' include the amount of work done by humans, coal, petroleum and waterpower, measured in millions of horsepower hour. Among the 30 countries, he listed five Latin American countries. Ranked by 'daily output per capita' these were: Chile, Argentina, Mexico, Peru, and Brazil. Read's results for 1939 did not alter this first Latin American energy ranking. ${ }^{34}$

R. Prebisch produced the first historical series of apparent consumption of energy for several Latin American countries for the ECLA's Economic Survey of Latin America 1949. ${ }^{35}$ The Survey, as the title indicated, had an essentially economic focus. Nonetheless, for each of the 4 countries analysed in detail (Argentina, Brazil, Chile and Mexico), there was a subheading dedicated to energy. Basically, Prebisch included the energy section in order to reinforce the 'dependence' argument elaborated throughout the text. No comparative effort was made though. In fact, the type of energies, the units displayed and the time span considered are different in each case: in the case of Argentina the units chosen were 'tons of oil equivalent', the items displayed domestic and imported fuels and the years 1925-48; for Brazil coal and hydroelectricity produced in the country plus imported fuels measured in million of kilowatthour for 1920-49; the only series displayed for Chile refers to the total amount of energy consumed quantified in millions of kilowatt-hour for 1925-1948, which apparently included firewood, coal, petroleum and gasoline; for Mexico coal, petroleum, natural gas and electricity add up to a total figure (the only one shown) given in millions of kilowatt-hours of energy consumed for 1925-48. 
A range of compound sources were used to assemble the Survey series: some estimates from the World Energy Conference, some data from national energy committees such as the Argentinean one, plus official data from yearbooks, national and international trade statistics, data from private companies such as hydropower companies, but also more obscure scholarly estimates of the time. Moreover, the equivalences established between the different energy carriers and the way apparent consumption was calculated remain unclear, especially for the countries where the total apparent consumption is the only figure displayed (Mexico and Chile). In some instances, the sources quoted are in-house estimates by the ECLA. The consistency of the series overall is doubtful, mostly when the ECLA itself declined to use the estimates of the Survey in its monograph about energy published within the decade.

The ECLA's concerns about the availability of energy in Latin America translated into a monograph dedicated exclusively to it, Energy in Latin America, published in 1957. The opening sentence of the monograph makes clear the importance of the matter: 'energy plays a decisive, albeit indirect role, in economic development, since, to the extent that it is available, it stimulates or hinders economic growth ${ }^{36}$ From this it derives that 'an increasing and rational use of energy is $(\ldots)$ essential for raising productivity levels and for remedying the technical and economic backwardness of under-developed countries in general, and of vast areas of Latin America, in particular' ${ }^{37}$ Furthermore, it asserts that 'the amount of energy consumed in the production process per worker can give a first indication of the degree of development of an economy ${ }^{38}$ In view of the outstanding role played by energy in economic activity, the main purpose of the study was to describe the characteristics of energy consumption in Latin America and to outline the future requirements.

Energy in Latin America put together basic statistical series on the various aspects of energy consumption for 20 countries of Latin America and the Caribbean. It aimed at covering the period 1925 to 1955 but 'in many cases it was not possible to complete the time series and hence only some characteristic years were presented, even if, on more than one occasion the procedure involved the use of estimates. ${ }^{39}$ For most countries the series go from the mid $1930 \mathrm{~s}$ to 1955 , and only for 7 countries estimates went beyond 1930. Mention should be made of the 
absence of Brazil from this last group, whose data are only given from 1939, completely ignoring the previous estimates of Prebisch. For the construction of the series no new data were elaborated, but estimates already published were used. As a consequence, the sources used differ greatly across countries. In the study, the countries are grouped in three categories according to the quality and detail of the statistical information available. The first one grouped the bestdocumented countries: Argentina, Brazil, Colombia, Chile and Mexico. These countries had a sizeable number of statistical compilations and specialised studies by 1957, although none covering the period prior to 1925 . In general, the data provided for these five countries are more reliable, or at least are more contrasted and sophisticated. ${ }^{40}$ The second group includes Cuba, Peru, Uruguay and Venezuela. For these countries, national yearbooks and trade statistics are combined with international sources, such as the United Nations Statistical Yearbook, plus some industry publication in the case of the oil producers (Peru and Venezuela) and the reports of the governmental energy departments where they existed. Far less information was available for the third group of countries, namely: Bolivia, Costa Rica, Dominican Republic, Ecuador, El Salvador Guatemala, Haiti, Honduras, Nicaragua, Panama and Paraguay. Few national statistics were used in these cases. Instead, United Nations statistics were chiefly used: the already quoted Statistical Yearbook, along with the Statistical papers. ${ }^{41}$

Possibly, the broadest historical energy study ever was the one directed by Joel Darmstadter (1971). ${ }^{42}$ It included data of commercial inanimate energy output, trade and consumption for about 100 territories covering the bench-mark years 1925, 1929, 1933, 1937, 1938, 1950, 1953, 1955, 1957 and the period 1960-65. Although it only produced two point estimates before 1930, it included 11 Latin American and Caribbean countries (Argentina, Bolivia, Brazil, Colombia, Cuba, Chile, Ecuador, Mexico, Peru, Uruguay and Trinidad \& Tobago), that is, the largest set yet for these early dates. This is a careful and detailed study. It offered the raw series (national production, exports, imports, bunkers and hydroelectricity) used in order to elaborate the apparent consumption of energy for each country. It made explicit all the conversion factors used for each type of energy carrier, including hydroelectricity (measured by heat content of the power produced rather than by coal-equivalent fuel requirements at 
thermal generating plants). Perhaps, the only weakness of this study, if it may be considered as such, is the massive use of secondary sources for trade data, mostly the United Nations (including ECLA) and the League of Nations estimates. Equally, for domestic production third parties estimates were almost exclusively used, namely the British Institute of Geological Sciences and the United States Bureau of Mines. ${ }^{43}$

From the preceding paragraphs, emerges that only three studies provide historical series of energy consumption in Latin America, namely ECLA (1951), ECLA (1957) and, Darmstadter et al.(1971). ${ }^{44}$ Respectively, they provide data for 5, 7 and, 11 Latin American and the Caribbean countries for the year 1925, the earliest considered. There is more than enough ground for our endeavour to estimate the energy consumption of these countries for the first quarter of the twentieth century.

\section{III}

Before starting to analyze the annual series, and with the purpose of firmly establishing the reliability of the data used, we present a comparison of foreign trade data of the Latin American countries and their main partners in 1925 for coal and oil. The choice of the year is in no way arbitrary: 1925 is the overlapping year with the existing series, none of then covering any previous year. In so doing, we make fully explicit the foundations of our estimates for the period 1890-1925.

By 1925, at the end of the period that we are studying, most Latin American countries were net importers of coal and petroleum products, mostly from the United Kingdom, the United States and Germany. Mexico and Peru also supplied petroleum within the region. Therefore, in order to estimate the apparent consumption of fossil fuels, it seems sound to approach the matter making use of the available trade statistics, and supplement those with home production data in the case of the extracting countries. Trade data can be obtained from the countries of origin from where the fuels were exported or, from the destination countries, which imported the energy. 
Of the 33 countries that constitute Latin America and the Caribbean at present, 18 published trade statistics in 1925, although only 15 offer sufficient detail about the country of origin and the type of products imported. From the exporter countries side, namely, United States (coal and oil), United Kingdom (coal), and Germany (coal), information is available, with varying degrees of detail, for all 33 territories. ${ }^{45}$ These three countries are referred to hereafter' as 'G3'. It is worth mentioning here the meticulous detail of the United States statistics, which turns out to be crucial for the data reconstruction of the smaller countries and territories, especially for the Caribbean.

A first look at the data offered by the importing countries reveals some useful trade patterns. ${ }^{46}$ As shown in Table 1, the 'G3' provided 98 per cent of the total amount of coal Latin America bought in 1925. The United Kingdom is the country with the greatest share, 69 per cent. The United States are next with a quota of 26 percent. Germany had much smaller shares (3.4 per cent).

A closer look at the coal trade patterns modifies somewhat the first impression. The United States was the main supplier (85-100 per cent) of coal for Cuba, Ecuador, El Salvador, Guatemala, Haiti, Mexico, Nicaragua and Dominican Republic, while for the larger consumers of the Southern Cone (Argentina, Chile and Brazil) the United Kingdom was the main supplier (60-80 per cent). Colombia and Peru showed no preference and imported similar amounts from these two suppliers. ${ }^{47}$ One main exception was Bolivia, which imported more coal from the neighbouring countries (mostly Chile) than from the G3 altogether. Coal entered the Argentinean market also from Chile. None of that coal was actually of Chilean origin. Finally, it must be noted that, although with small relevance for the overall trade, other suppliers were also involved: Australia supplied Chile and the Netherlands both Chile and Argentina.

\section{[TABLE 1: coal trade patterns, quantities]}

In the case of petroleum, regional trade played a much greater role. Seven Latin American countries were oil producers by 1925 -Argentina, Colombia, Ecuador, Mexico, Peru, Trinidad \& 
Tobago and Venezuela-. Together they amounted to 15 per cent of the world's petroleum output, while the United States represented 72 per cent. In other words, Latin America extracted more than half of the petroleum obtained outside the United States. At the same time, Mexico continued to be the second largest oil producer in the world, a position briefly lost to the Soviet Union, only to be regained by Latin America three years later by Venezuelan wells.

Three countries were the main suppliers of oil products to the region, United States, Mexico and Peru. A little more than half of the oil imported by Latin American countries had its origin in the United States, as can be seen in Table 2. Although the United Kingdom and Germany are sometimes mentioned as suppliers of oil products in the trade statistics of the Latin American countries in 1925, they provided negligible amounts. This helps to explain why petroleum trade to Latin America is mostly invisible in British and German statistics. The remaining half of the oil was mostly supplied within the region.

Mexico supplied 40 percent of the tonnes imported according to the importing countries data. Peru, the third main producer of the region, provided 8 percent. It may be worth mentioning that while the Venezuelan petroleum output was much greater than the Peruvian one, the former massively exported crude to refineries of the Dutch West Indies (Aruba, Curacao). From there it was re-exported, mostly to the United States and Europe. Direct exports from Venezuela to the rest of the region remained very low, with the exception of neighbouring Colombia. The list of alternative suppliers is larger than in the case of coal, but they had a small weight on the overall trade and mostly acted as mere intermediaries. So for instance, the main oil supplier to Bolivia was again Chile, while for Colombia most of the petroleum products came from Costa Rica. This clearly demonstrates the role of intermediaries played by some countries in the case of oil (Panama is the other main case).

[TABLE 2: Petroleum trade patterns] 
One main message distils from this first look at the data. Theoretically, it would suffice to collect data from three exporting countries to cover over 90 per cent of the fossil fuels imported by the Latin American countries. Nevertheless, all the data available at both ends, importers and exporters, were collected for the comparison exercises in this part of paper since a priori, the more data collected the more refined the new estimates would be. The approach taken presents a number of inconveniences and methodological challenges that need to be discussed in order to elaborate the new estimates. These were grouped in three main kinds: 1) problems of classification and units of measurement; 2) contrast of volumes between the data provided at origin by the exporting countries and the data registered at the country of destination by the importing countries; 3 ) methodological problems in relation to the consumption of home produced coal and petroleum. Some of these needed lengthy and detailed discussions, clearly exceeding the size of one single paper, and can be found elsewhere. ${ }^{48}$ Details aside, no more than the main issues and decisions made regarding contrast of sources and methodology are offered here.

The total figure of coal and petroleum imports according to their own domestic sources was obtained for 17 countries. For 15 cases it was possible to distinguish the country of origin of the products. One way of checking the reliability of the standardization criteria was to contrast these data with volumes registered in the country of origin by the exporting countries. Among the main reasons for using all the available data was the general, but not definitive, pessimistic tone of economists, economic historians and Latinamericanists alike, regarding the poor quality of trade figures in general. The issue of the (in)accuracy of the foreign trade statistics remains in the economic literature to the present day. ${ }^{49}$ Yet, in historical terms, the accuracy of foreign trade statistics seems to be more robust than generally thought. ${ }^{50}$ Regarding Latin American trade statistics, the position is somewhat mixed although traditionally pessimistic. ${ }^{51}$

In the absence of evidence in the literature, we needed to test for ourselves the level of accuracy of the trade statistics at both ends. There is a wide array of potential matters that could help to explain the expected differences between the volume and value annotated at the port of origin and the registered at destination: different accounting methods (CIF versus FOB, fiscal 
versus calendar years, etc), pricing methods (official, declared, fiscal...), misclassification of products, etc. Nevertheless, the data match is surprisingly acceptable.

Consider first the case of the quantities of coal imported from G3 shown in Table 3. The contrast of the volume imported according to both types of sources reveals that for a first group of countries a very close match (2 to 7 per cent differences): Argentina, Brazil, Colombia, Cuba, Dominican Republican, Ecuador and Nicaragua. A second group of countries (Chile, El Salvador and Peru) exhibits a less satisfactory correspondence, with differences between both sources on the 15-35 percent range. Finally, four countries show irreconcilable differences, measured in percentages, between their statistics and those reported by the exporting countries, these are Bolivia, Costa Rica, Haiti and Mexico. But even for these countries, the actual amounts of tonnes missing are very small to have a significant impact on the impression we get from a country as a small, medium or large consumer of coal whichever source we look at. When the region is taken as a whole, and the coal exports recorded to Latin America by G3 are confronted with the total aggregated imports as declared by the destination countries, the gap reduces to 1 per cent of the total.

\section{[TABLE 3: Coal quantities contrast by source]}

In the case of petroleum products the contrast must be done in absolute and comparable totals. The absolute totals shown in Table 4 (panel A) simply contrast the total amounts of petroleum registered by the importing country with the aggregation of the exports to that country reported by the United States, Mexico, Peru, Argentina, Chile, Germany and the United Kingdom. These are not exactly comparable magnitudes. On the one hand, there may be alternative suppliers included in the total amount reported by the importing countries. These alternative suppliers -Venezuela, Puerto Rico, Panama- are not included in the figure summed from the exporters data. On the other hand, exporters (especially the United Kingdom and Germany) may not report quantities sold to small countries, but these amounts show up in the 
Latin American home statistics. With the absolute totals the contrast of quantities between both sources is dismal.

\section{[TABLE 4: Contrast of petroleum data]}

When the contrast is made solely on the basis of the comparable data, the gap improves for most countries. Table 4 (panel B) report the results. Comparable totals only include the amounts for which information is available at both ends. Comparable totals add up the same set of countries. Except for the cases of Colombia, Ecuador and Dominican Republic where a sizeable number of tonnes are missing from the home statistics, for the rest of the countries the match between tonnes reported at origin and at destination port is acceptable. ${ }^{52}$ Since the countries with the greater divergences are the small consumers, the gap between importers and exporters data of the total for the region is as small as 2 per cent. The impact of these differences on the final estimates of apparent consumption per capita of individual countries are however relatively small.

An important question remains regarding the statistical significance of these gaps. How wide should the difference be in order to be sure that these figures are statistically different? This question goes beyond the topic of this paper and has been discussed elsewhere with very positive results. The conclusion of the several exercises performed is that only in very few cases, we can accept the existence of statistically significant differences between the data provided by the exporters and the data registered by the importing countries. ${ }^{53}$

A last methodological matter needs to be briefly discussed: the estimation of the consumption from home produced fuels. The figures of domestic production of coal are available for Latin America, yet without sufficient detail regarding the types of coal produced. ${ }^{54}$ In the case of petroleum, the estimation of consumption from domestic production is slightly more complex. While Argentina, Colombia and Ecuador consumed domestically the oil they extracted, most of the oil extracted in Mexico, Peru, Trinidad and Venezuela was exported. ${ }^{55}$ 
There are not many problems with the former group, apart from not knowing to what use the oil was put to. So for this group the domestic production is simply added to the imports. The exporters are more problematic. If they only exported crude oil, the amount of oil left for domestic consumption would be the difference between production and exports. Since their exports included derivatives, the estimate of domestic consumption from home production is not so simple. It was estimated that by 1925 , the by-products from a barrel of 42 gallons of crude oil were: 20.7 gallons of fuel oil, plus 13.6 gallons of gasoline and naphtha, some 3,4 gallons of kerosene, and 1,8 gallons of lubricants; the rest, about 2,5 gallons was lost in the process. ${ }^{56}$ In other words, 6 per cent of the volume was lost in the process of refining and was no longer available. ${ }^{57}$ These figures were taken into account in order to avoid the over-estimation of the amount of energy disposable for these countries. ${ }^{58}$ Once imports and consumption from home production were estimated for coal and oil, they were aggregated into a single figure of apparent consumption of fossil fuels, converting all units to tonnes of oil equivalents using the standard conversion factors of the IEA.

The aggregation of trade and domestic production of coal and petroleum allows the elaboration of new estimates of apparent consumption of fossil fuels per capita for Latin America and the Caribbean countries in 1925. The new estimates for 1925 were elaborated for both the foreign and the domestic sources. The foreign sources provide data for 32 territories; with the domestic sources, alternative estimates can be elaborated for 17 countries. The contrast of these two elaborations with the estimates previously available for the same year of 1925 (ECLA 1949 and 1957, plus Darmstadter 1971) is shown in Table 5. The new estimates withstand the test entirely. The robustness of the new estimates in relation to the old ones supports the new estimates for which no previous reference existed (Barbados, Bermuda, Dominican Republic, Honduras, Jamaica, Nicaragua, all of the West Indies -Danish, Dutch, French and British- Panama, Paraguay and, Venezuela).

[Table 5: comparison of new vs. old estimates] 
The proportions of coal and petroleum in the apparent consumption of energy deserve some attention in relation to modernisation issues. ${ }^{59}$ The fact that for the Central American countries, coal was mostly irrelevant already by 1925 provides an interesting hint. Had they been involved in the technologies of the first industrial revolution, they would have used coal. It seems these countries never made use of the classic steam engine, but made a jump straight to combustion engines, thus to petroleum products. The United States' technological leadership on this technology and its influence in this area also support this hypothesis. On the contrary, the countries of the Southern Cone made great use of coal. In fact, Argentina, Chile, Uruguay and Brazil consumed more energy from coal than from oil, and together consumed more than half of the coal consumed in the region (Panama excluded). Two possible explanations can be advanced for this fact. On the one hand, these bigger countries initiated their industrialisation process during the nineteenth century, thus tying their energy consumption patterns to the prevailing coal technology. On the other hand, path dependence also affected trade. In this regard, the strong historical commercial relationship of Argentina with the United Kingdom adds a further bias towards coal.

The encouraging results of the exercises in this section prompt us to extend the new estimations using the foreign sources as the keystone of our reconstruction backwards to the 1890 s, since absolutely no estimates of energy consumption are available before 1925 . Yet in order to achieve a more complete view of the consumption of modern energies, we need to take into account the newest energy of the time: hydroelectricity.

There is very little information regarding hydroelectric production in Latin America at this early stage; the closest in time is the one by the United Nations which produced an estimate of the hydroelectric production in Latin America by 1929. We projected backwards the electricity production of 1929 using the stock of electrical generators of each country. Assuming that no electrical machinery was produced in the whole of the subcontinent, for the construction of the stock of electricity generators we used again the trade statistics, this time those of the US, the United Kingdom, Germany and Switzerland. We assess the value of the stock of imported 
generators, and we deflate it with the estimated Swiss export price index of electrical machinery. These series are transformed into hydroelectric production using the factor found for 1929. ${ }^{60}$ Nevertheless, the figures of hydroelectric power we obtain have almost no impact on the total energy consumption levels of most Latin American countries, except for the smaller Central American countries, especially Costa Rica. This is shown by contrasting the numbers of fossil consumption (in Table 5) with the ranking of total modern energy consumption (Table 6).

The sum of imports, established with the G3 data allow us to cover 30 countries and territories, plus national production of modern energies (net of exports), including hydroelectric power, constitute our indicator of apparent consumption of modern energies; divided by population is the gauge we use through the rest of the paper.

\section{IV}

Table 6 offers the ranking of energy consumption per 1000 habitants for 1890, 1900, 1913 and $1925 .{ }^{61}$ Leaving aside the colonial possessions for the moment, the first thing that draws our attention is the wide gap in modern energy consumed across the subcontinent. In 1890, the average Uruguayan citizen disposed of 730 times the energy (specifically coal) of an average Salvadorian or Guatemala's habitant. By 1900 close to nothing had changed, but in 1913 and 1925 the difference widened even more once Panama entered the list. Excluding Panama, given its exceptionality discussed below, the five countries above the regional average (weighted) Uruguay, Chile, Argentina and Cuba-, consumed in 1890, 17 times more per capita than the twelve countries below the average; the proportion was reduced to 12 times by 1900 , and remained thereafter (13 times in 1913; precisely 12 by 1925).

From this depiction, it is clear that the differences in the levels of economic modernisation across Latin America were already present by 1890 and changed very little in the following decades. The early integration to world markets seems to be as important as the natural endowment. Among the large consumers only Uruguay and Cuba had absolutely no national production of modern energies. Yet Uruguay has been present in the world market since the first 
half of the $19^{\text {th }}$ century with its 'tasajo' exports and Cuba was the first supplier of sugar to the international markets from the 1830s; Chile was well endowed with mineral coal for home consumption, but also with silver and cereals first and, nitrates and copper later for exports. Argentina joined later, but with force, the international trade flows.

\section{[TABLE 6 : Levels of energy consumption per capita in LA\&C]}

Another potential explanation lies with the opportunity cost of the transition from traditional energies of organic origin to modern fossil fuels. While Uruguay and Argentina had no option but the fossils, for their rich regions of the pampas did not offer much to burn as energy, the cases of Cuba and Chile -better endowed with wood and sugar cane for burning- are better explained by the fact that their export activities grew much faster than the organic energy they could provide. In this regard, it is quite possible that the countries with access to the Amazon (Brazil in particular, but also Peru, Ecuador, Colombia and Venezuela, plus the Guianas) had higher opportunity costs for modernising given the abundance of wood. In the small economies of Central America and the Caribbean, always in the end positions of our modernisation list, the handicaps collude: a poor natural endowment, a late integration in the world markets and the perpetuation of traditional small economic activities, made it possible to continue without much need for modern energies. For these economies, the energy surge came with the delayed arrival of railways, in fact the larger consumer of modern energies of the time.

It is clear that the differences in the levels of energy consumption per capita were already present by 1890 . Also the existence of clusters of countries (large vs small consumers) was also present from the beginning. Uruguay, Chile, Argentina and Cuba are the four countries at the head of economic modernisation -see Figure 3, below-. Reporting of Argentina as a rich a prosperous country is common place in the economic history literature. ${ }^{62}$ What is somehow surprising here is that it does not take the first position in our indicator of economic modernisation. Yet, as said earlier, our indicator tends to push upwards industrial, mining, 
commercial and/or urban countries and push downwards predominantly agrarian and/or rural economies. Therefore, the explanation for the Argentinean case surely lies within the marked agricultural profile of its economy, which implied relatively low modern energy consumption (limited to the railways and the urban centres). By contrast, the mining intensity of the Chilean economy, which needed to melt its copper before export, and the extensive and dense railway network of Cuba, plus their key role as bunkering ports in the main commercial routes help us to understand their higher levels of energy consumption. In the Cuban case, the increase of modern energies is a further indicator of the replacement of the traditional organic fuel of the sugar industry: the sugar cane bagasse resulting from the crushing process which traditionally fuelled the industrial process. Bagasse was first replaced by mineral coal and later on by petroleum. For its part, Uruguay appears as the largest consumer of modern energies, by some means an unexpected position. Sharing the traffic of the River Plate with the Argentinean colossus, it is possible that even if only a few of the bunkering activities of Montevideo's port actually corresponded to ships entering or departing from Buenos Aires, our per capita estimate for Uruguay would come down -given the large scale of the port activities relative to the small population of the country. ${ }^{63}$

As noted earlier, the position of Panama is exceptional. With US backing, Panama seceded from Colombia in 1903 and promptly signed a treaty with the US allowing for the construction of a canal and US sovereignty over a strip of land on either side of the structure (the Panama Canal Zone). The Panama Canal was built by the US Army Corps of Engineers between 1904 and 1914. Over the construction period, but overall once opened, the Canal received huge amounts of coal and petroleum for bunkering purposes. With less than half a million inhabitants it is implausible that the Republic of Panama consumed between half and a million tonnes of oil equivalent however prosperous the former Colombian province might have been. It is not possible at this time to distinguish between the energy consumption of the Republic of Panama and that of the Panama Canal. As a bunkering post, the consumption of the Canal was among the highest in the region. Most of the Caribbean colonial possessions must also be considered as 
bunkering stations of their metropolis, thus their energy consumption has to be taken with precaution.

Oil producers within the region deserve special attention. ${ }^{64}$ Mexico closed the gap with the leaders over the 1920s but still did not reach the top of the list. Petroleum abundance was not per se an advantage at that stage -they consumed very little of it and mostly related to the petroleum industry itself- a clear symptom of the difficulties for modernising their economies. It was not easy to shake off the burden of the predominance of activities based on organic energies and the late integration in the world markets, both rooted in the pre-1890 period.

[Figures 3 to 9: Tonnes of oil equivalent per 1000 habitants by country 1890-1925]

Among the countries in the midrange of Table 6 we find Brazil, the largest country in the region by most measures. ${ }^{65}$ Although it manages to increase its consumption per capita, Brazil loses positions in the ranking, which is probably related to the opportunity cost of switching to modern energies for a country with huge woodland resources. In fact, the only jump for Brazil occurs between 1900 and 1913, and for the last period energy consumption levels fall slightly. The Peruvian case is similar to the Brazilian, one of losing positions, but it is different inasmuch as Peru was the oldest of the oil producers of the region. The evolution of these two countries can be observed in Figure 3. While Peru stagnated from 1908 reflecting exhaustion after the effort of the preceding decades of overlapping petroleum, copper and silver surges ${ }^{66}$ Brazil interrupted its progress with the outbreak of First World War, which severely hurt its coffee trade, and did not recover until 1925. In this group of midrange consumers of Table 6 we also find Costa Rica and Puerto Rico. The former surpassed Brazilian and Peruvian levels of energy consumption after the war, the latter carried on losing positions, being unable to keep pace with Cuba.

At the bottom of Table 6 the same countries are systematically found: Haiti, El Salvador and Guatemala, a group of small and poor economies in Central America and the Caribbean -see Figures 5 and 6-. ${ }^{67}$ The trajectory of Haiti earns by its own merits the category of "regional 
minimum" by 1925 and allows it to be described as the least developed country in the region. The worst of it all is that it was not so at the beginning. Haiti is a story of decline in the long run, especially from 1896 through 1905, and from 1913 through 1919, barely compensated for by the period in between. On the other half of the island, in contrast, the Dominican Republic moves in the opposite direction: only up (with some minor downs). So it does Honduras, which by 1925 already reached the levels of Costa Rica, in part thanks to the railway construction initiated in 1913, undertaken by US investors.

El Salvador could have turned into another 'Haiti', where lethargy set in. But from 1910 it slowly started its modernisation process, hardly noticing the effect of the First World War, all explained by the railway construction by foreign investors. The same factor explains the growth of Guatemala from 1895 to 1913, which basically stagnated after experiencing very little or null modernisation besides the railway itself. The only exception in this respect may be Nicaragua, whose levels of energy consumption continued to increase once the expansion of the railway network concluded. This strong relationship between the size of the railway network and modern energy consumption by 1890 can be seen in Figure 10.

[Figure 10: Energy consumption (toe) and railroads (km) per capita in 1890]

A final separate group is constituted by the Andean region, Colombia and Ecuador (and the landlocked Bolivia and Paraguay (for whom insufficient data prevent us from offering confident time series data at this time). Colombia suffered the secession of Panama and it did not recover until the 1920s. Ecuador is more like Honduras and the Dominican Republic, despite increasing levels of energy consumption per capita, it is not enough to leave the bottom of the ranking.

The comparisons and contrasts reveal clearly that for most of the Andean and Central American regions the first globalisation was nothing more than a lost opportunity. In contrast, a few other small economies, such as Costa Rica, Panama, Dominican Republic, Jamaica or Puerto Rico, managed to find their niche in the world economy. They made the most from it, but the benefits were not always capitalised on the longer run. Latin America and the Caribbean 
fragmented into portions that pursued modernisation at very different paces. The emergence at this time of regional clusters is a relevant finding.

Finally, it is possible to make a more precise assessment of the modernisation levels of the region in contrast with two other economies: the US and Spain. The distance to the world leader, the US, was abysmal even for the most modern of the Latin American countries. The average Latin American citizen consumed less than 2 percent of the energy consumed by the representative US citizen throughout the period. But the US was already the most energy intensive country in the world. A more realistic comparison is the one with Spain. Relative to Spain, the leader countries of the region -Argentina, Chile, Cuba, Uruguay, even Mexico by the mid 1920s- have higher energy consumption per capita than Spain. The implication is that these five were more modern countries than Spain. This proposition is further grounded if we consider that it is fully consistent with the standard knowledge on GDP and migratory flows over the period. Yet, this contrast, also reveals how far from modernising where most of the rest of the countries of the region: consuming less than a tenth of the level of a country still on its way to modernity as was Spain at the time.

In a second level of examination we focus on the different chronologies of the economic modernization of the regions. There is a clear-cut difference between the pre First World War era -with high modernization rates (5.1 per cent yearly per capita modern energy consumption growth)- and the war and post war era -when modernization slowed down (1.9 per cent yearly growth per capita). The first period $-1890-1913$ - has been properly described as the first globalization, or the years of the making of an integrated international economy. According to the best of our knowledge, some Latin American and Caribbean countries fully enjoyed the opportunities provided by the increased specialization and integration of the world economy. All these opportunities implied a larger consumption of modern energy sources. 


\section{[Table 7: Rates of growth of per capita modern energy consumption (\%)]}

The figures in Table 7 provide data to support this view. The whole of the region had a yearly increase in modern energy per capita consumption of 5.1 per cent. It more than trebled. The large Latin American economies had a growth rate in the same range: Argentina, 4.7, Brazil, a bit lower, 3.7, but Mexico, much higher, 11.0. Mexico manages to change from an underperformer in Latin American terms to an over performer. These are the years of the "porfiriato", up to the abrupt revolutionary interruption of 1910. The "medium" size progressive economies also enjoy a good time: Cuba at 5.5 per cent, Chile at 4.8 , but Uruguay, perhaps the richest by 1890 , only 2.1 . These six countries represent 83.8 per cent of total modern energy consumption in 1913 Latin America. But a number of other small countries are also showing amazing performances. Guatemala shows a 20.1 per cent growth rate, Ecuador a 14.2 per cent, Honduras, 12.4, Costa Rica, 8.6, Peru, 7.5, El Salvador, 6.9. All of them, but Peru, were small countries -in population terms-, in the tropical region, and initially very poor. They jump from extremely low levels of modern energy consumption per capita to simply low levels.

On the other hand, a few countries fully missed their opportunities: Colombia is the most spectacular with a -4.0 per cent, Venezuela, -1.3, Nicaragua, -0.3, and Haiti, 2.4. The Colombian case is highly interesting as it reflects the loss of its wealthiest province -Panama, independent from 1903. It is unfair to consider both countries as separate entities, as what remained of Colombia was much poorer by 1903. If we consider Colombia and Panama together what we get is a yearly increase of 10.5 per cent, close to the Mexican levels for instance. The other three cases seem real. By the early 1890s Nicaragua enjoyed some advantage compared with most Central American economies (except Costa Rica) but could not sustain it subsequently, and there could have been some intraregional convergence. The energy data suggest that such a trend did exist: Guatemala and Honduras overcame Nicaragua and approached Costa Rica. Only El Salvador remained stagnant. 
Venezuela and Haiti do not have any excuse for their underperformance. Haiti is the most intriguing country, as it becomes the poorest one -in per capita energy consumption termsprecisely during these years. At the starting point Haiti was on the same range than Dominican Republic -the other half of the Hispaniola island- or Colombia. By 1913, after more than two decades of low growth, it was close to the bottom. Haiti reached this position during the War. The very small colonial territories followed quite different paths, generally positive, but with some curious exceptions such as British Guyana.

It is worth highlighting the fact that the highest growth rates correspond to the Andean axis, from Mexico to Peru. The temperate Southern countries did well, but just below the average. Brazil, and mostly Uruguay and Venezuela appear as clear underperformers. The region as a whole managed to increase its modern energy consumption a third quicker than the US. A catching-up experience, but it was not spectacular. Neither was the intraregional catching up spectacular. For all the rapid growth of the poorer countries that our figures unveil, the fact is that the 1890 ranking was quite similar in 1913. Only Mexico made a promising difference.

A closer look at the Latin American average evolution suggests an accelerating trend, particularly since 1902 , peaking in 1911 . The $1890-1902$ growth rate for the whole region is 4.5 , while 1902-1911 jumps to 8.1. A more conventional breakdown into decades -before and after 1900- provides the same acceleration trend -but a bit blurred- from 3.6 in 1890-1900 to 6.4 in 1900-1913. The acceleration is quite general, with clear upturns for Argentina, Brazil and Chile, that jump to the 6-8 range in 1900-1913 from one per cent per year or less in the last decade of the nineteenth century. The only significant economy experiencing the contrary movement is Mexico, that goes down to 3.6 from 21.4. But this can be explained by the Mexican Revolution. Indeed, growth rates outside Mexico during the "Edwardian era" are really impressive. Only Uruguay experiences slow growth (1.9 per cent). The comparison with the US figures underlines the strong dynamism of the early twentieth century economic upswings for the whole of Latin America, even compared with the world energy consumer leader.

We usually accept that Revolutionary Mexico suffered from an acute shortage of data. Our modern energy consumption approach, using exports from the major western economies, allows 
us to overcome a bit of this shortcoming: our figures go down one third from 1910 to 1914 . But the road down includes a very good 1911, and the strong recovery after 1914 has to be underlined.

The outbreak of the First World War was a watershed for Latin America, as for the rest of the world. It is fair to mention that the years immediately prior to the war were of economic crisis or deceleration for some of the large economies (Argentina, Brazil, Mexico and Uruguay), with a 10.8 fall from 1911 to 1912, only partially recovered in 1913. The overall Latin American and Caribbean performance was quite bad: 30.2 per cent fall from 1913 to the through of 1919 (and a 35.1 fall if comparing 1911 to 1919). Contrary to what happened during the pre-war globalization years, when the per capita energy consumption was growing for almost every country, the war years showed very different country experiences. If we focus on the period 1913-1918, when most of the impact was felt, we have countries with yearly growth rates ranging from -33.0 per cent in Guatemala to +24.7 per cent for its neighbor Honduras. These extremes were not isolated. The largest economies also experienced such a discrepancy. Argentina fell at a 29.0 per cent rate and Brazil at a 15.6, but Mexico grew at 11.5. Uruguay went down at 14.5 and Chile at 5.3, but Cuba remained almost stagnant (-0.1). The downs were more important than the ups, as happened with the whole of the region (-6.2), but what is the most striking is the diversity of the experience, even among close neighbors. Generally speaking, we know and we see that all the economies closely linked with the European markets -United Kingdom, mainly, but also Germany and France- suffered the most the war. This was the case of all the large South American economies -Brazil, Argentina, Chile and Uruguay-, and for some others like Guatemala (-33.0), Costa Rica (-23.8), Haiti (-17.2), Jamaica (-14.5), in Central America and the Caribbean. But these were the only eight economies suffering more than the average ${ }^{68}$.

A number of economies enjoyed positive growth during the war years. Below the Honduras maximum rate we have Nicaragua (18.6), Venezuela (17.9), Dominican Republic (13.6), El Salvador (12.9), Mexico (11.5), Trinidad \& Tobago (3.2) and Peru (1.3). Panama (-3.2), 
Ecuador (-3.6), and Colombia (-5.1) were in the negative range, but above the regional average, just as the previously mentioned cases of Chile (-5.3) and Cuba (-0.1).

The fluctuations during the war years unveil a number of country and regional features. Argentina reduced its energy consumption at an accelerating rate, mirroring the war economy developments in Western Europe: increasingly poor economic conditions and increasingly risky and expensive freight rates. It is not surprising that the worst moment was 1918, at 18 per cent of the 1913 value. Brazil, on the contrary, suffered a tough decline in 1914 and 1915, much smoother from 1916 to 1918 , when a minimum was reached of the 42.8 per cent of 1913 . It is likely that Argentina reflected the pattern of the wheat and meat European importing markets, both difficult to compress. Brazil reflected the coffee and the colonial European importing markets, a luxury that could be skipped from the start of the war. Indeed, the only Latin American countries to suffer a long and deep fall during the First World War were of the Argentina or of the Brazil kinds: Costa Rica, Guatemala and Uruguay, a total of five. Two of them large economies, and one more a medium size prosperous economy, The other two small and poor, even if promising. But it is impossible to distinguish, for other countries, anything similar to what they suffered.

Mexico fully recovered from the Revolution. The 1911 maximum was difficult to reach, but it is impossible to draw a negative picture of 1914-1918. Cuba also enjoyed relatively good years, around 1911-1913 levels: not extraordinary, but not bad. Chile had a poor 1915, but the other years were in the 1910-1913 range, and much better than 1912. There was the occasional bad year, like in Ecuador (1915) or in Jamaica (1918), but the norm was stability or stagnation. It is also difficult to find big spurts, although Honduras, Nicaragua, Dominican Republic and El Salvador are cases in point. They were small economies, but they enjoyed -without doubt- a golden era during the First World War.

Can we assign any responsibility for what happened to the Panama channel? As we know, it was inaugurated in mid 1914, and was itself a real watershed in American life. Were the poor performance of the South Atlantic economies and the relatively good development of the Pacific rim linked to the new shipping routes opened by the Panama channel? It is quite likely. Our 
figures suggest that this interpretation could be true. Mexico and the Central American Republics, that happened to be just in the middle of the new route from the US East and West coasts did quite well. The Andean countries reduced dramatically their distance from the Northern Atlantic world and could enjoy many more business opportunities. On the contrary, Brazil, Uruguay and Argentina had to be net losers.

For a few economies the worst came in 1919. Recovering from the Great War was not easy at all. For the whole of Latin America 1920 seemed to be the recovery year, but 1921 did not continue the growth trend, and 1922 collapsed again. Only 1923 provided a better performance than any previous year, including 1911. The following years, 1924 and 1925 confirmed the recovery and the new growing trends. As far as we can see with our figures, three economies were outstanding from 1920 to 1925: Honduras (25.1), Panama (25.4) and Colombia (47.0). The dynamism of Colombia and of Panama had local roots in the success of the Channel, for Panama, and in the combination of coffee exports and early import substitution policies in Colombia. Ecuador (10.1), Dominican Republic (8.8), and Costa Rica (8.8) also did rather well.

In relation to the US it is interesting to note that the gap did not widen. It is true that the gains obtained over the first decade of the $20^{\text {th }}$ century were completely eroded in the War. Yet, the recovery up to 1925 placed Latin America relative to the US at the same level it was by 1910. The evolution with respect to Spain is more clearly convergent throughout. While the regional average energy consumption was below 40 per cent of the Spanish consumption in 1890, by 1925 the region had achieved 60 per cent of the ex-metropolis consumption.

\section{VI}

In the absence of comparable macroeconomic indicators for most of the Latin American economies before the 1930s, this paper presents an estimate of the apparent consumption per head of coal, petroleum and hydroelectricity for 30 countries of Latin America and the Caribbean for every year from 1890 to 1925 . This allows us to rank the Latin American countries and observe the changing relative distance among each other. To construct our 
estimates, we first contrast both the statistics of the Latin American economies and that of their principal trade partners by 1925, and then rely on the trade partners data to reconstruct backwards to 1890 . To these we add data on home production of coal, petroleum and hydroelectricity. We use energy consumption as an indicator of economic modernisation.

As a result, the paper contributes to several literatures. On the one hand, it offers a contrast of the foreign trade statistics of the Latin American countries with that of the advanced economies (United Kingdom, United States and Germany), showing that the former are far more reliable than previously thought by the literature. On the other hand, the paper adds to the environmental and energy history studies by doubling the number of countries for which energy consumption estimates were previously available in Latin America. Last but not least, the paper contributes to the wider economic history debate in Latin America providing the basis for a comparative analysis of modernisation performance, beyond the countries for which historical national accounts are currently available.

According to our new estimates of energy consumption per capita, and taking it as a proxy of economic modernisation, we find that Argentina, Chile, Cuba and Uruguay were already well ahead of all the others by 1890 (when our series start). On the contrary, the small Andean and Caribbean economies failed to start their modernization until just before the First World War, when foreign investment in railways impacted on their traditional economies. Social archaism and a very tiny domestic market were strong brakes against further progress. Brazil, Mexico and Peru were around the Latin American average. Their modern sectors, grounded in mid-nineteenth century, were unable to push traditional activities out of their archaism.

In a more general way, we demonstrate that countries differed in their ability to benefit from the opportunities created by the first globalisation; that the First World War did not have the same impact across the region; that, clearly, Latin American economies had heterogeneous experiences in their recovery from the war. Finally, the entire region, up to 1925 , remained at a very low level of modern energy consumption; consequently, we conclude that despite the undeniable degree of advance made over the first quarter of the $20^{\text {th }}$ century, the degree of economic modernisation reached by Latin American countries was overall patchy and uneven. 


\section{APPENDIX: Data Sources}

- COAL and PETROLEUM bought by Latin America and the Caribbean countries:

Domestically produced statistics of each country quoted under official publications below

- COAL and PETROLEUM sold to Latin America and the Caribbean countries by:

Germany, Der Auswärtige Handel Deutschlands, (Berlin, various years)

México: Departamento de Estadística Nacional, Anuario Estadístico: Comercio exterior y navegación (México D.F., various years). -OIL ONLY-

Perú: Superintendencia General de Aduanas, Estadística especial del Perú (Callao, various years). -OIL ONLY-

United Kingdom: Statistical Office of the Customs and Excise Department, Annual Statement of the Trade of the United Kingdom with Foreign Countries and Britain possessions (London, various years).

U.S. : Department of Commerce, The Foreign Commerce and Navigation of the US (Washington D.C., various years).

- COAL produced and exported by Latin America and the Caribbean countries:

Argentina (coal re-exports): Dirección General de Estadística, Anuario del comercio exterior de la República Argentina (Buenos Aires, various years)

Chile (coal production):

For 1890-1902: Boletín de la Sociedad Nacional de Minería (various years).;

For 1903-1907: Oficina Central de Estadística, Estadística minera de Chile;

For 1908-1930: Dirección General de Estadística, Anuario de Minería: Minería y Metatlurgia. (Valparaíso, various years).

Chile (coal exports): Oficina Central de Estadística, Anuario Estadístico de la República de Chile: Comercio Exterior (Valparaíso, various years).

Brazil (coal production): Martin, Jean-Marie .(1935). Processus d'industrialisation et développement énérgetique du Brasil. Paris : Institut des hautes études de l'Amérique Latine

México (coal production): Instituto Nacional de Estadística Geografía E Informática (INEGI) (1994): Estadísticas Históricas De México. México D.F. pp.472

Perú and Venezuela (coal production): Mitchell, B. R. (2003) International Historical Statistics. The Americas 1750-2000, Fifth Edition. Palgrave Macmillan

-PETROLEUM produced and exported by Latin America and the Caribbean countries:

Argentina, Colombia, Ecuador, México, Perú, Trinidad \& Tobago, (petroleum production): American Petroleum Institute, 1937. Petroleum Facts and Figures. New York. pp.56-57

Argentina (petroleum exports ): Dirección General de Estadística, Anuario del comercio exterior de la República Argentina (Buenos Aires, various years)

Colombia (petroleum exports ): GRECO, Comercio Exterior y Actividad Económica de Colombia en el siglo XX: exportaciones totales y tradicionales, (Bogota, 2002 mimeo)

Ecuador (petroleum exports): estimated at 90 per cent of production.

México (petroleum exports): Rubio Varas, M.d.M., 2002. Towards Environmental Historical National Accounts for Oil Producers: Methodological Considerations and Estimates for Venezuela and Mexico over the 20th Century. PhD, London School of Economics, London.Appendix B.

Trinidad \& Tobago (petroleum exports ): Mitchell, B. R., 2003. International Historical Statistics. The Americas 1750-2000, Fitth Edition. Palgrave Macmillan

Perú (petroleum exports): Superintendencia General de Aduanas, Estadística especial del Perú (Callao, various years).

Venezuela (petroleum production and exports ): as in Mexico

\section{- HIDROELECTRICITY (production estimates)}


Tafunell, X., 2006. 'Nota explicativa sobre el procedimiento de estimación de la producción hidroeléctrica' (mimeo,)

-POPULATION of Latin American and Caribbean, republics, colonies and territories:

Mitchell, B. R., 2003. International Historical Statistics. The Americas 1750-2000, Fitth Edition.

Palgrave Macmillan

Except for:

Barbados 1890-1909, Bermuda, Bolivia 1890-1900, British Honduras, Colombia 1890-1900, Cuba 18901900, Dutch Guiana 1920-1930, French Guiana 1900-1930, Guatemala 1890-1900, Honduras 18901900, México 1890-1892, Paraguay 1890-1900 and Venezuela 1890-1900, constructed by interpolation using the census data offered Mitchell, B.R. (2003).

1890-1900 for Dominican Republic, Ecuador, El Salvador Haití, Nicaragua and Panama, where no census data were available then the cumulative yearly growth rate of the population data for this countries by Maddison, A.; The World Economy: Historical Statistics, (OECD, 2003) were used to backcast Michell's data.

Bulmer-Thomas, V., 2001. 'The Wider caribbean in the 20th century: A long run development perspective', Integration and Trade, Sept-Dic, v. 5 iss 15:

For 1900-1930: Danish West.I.I., Dutch Guiana, Dutch West.I.I. and French West.I.I 


\section{References}

Abosedra, S. and H.Baghestani. 'New evidence on the causal relationship between United States energy consumption and gross national product', Journal of Energy and Development 14 (1991), pp. 285292.

Akarca, A. and T.Long. 'On the relationship between energy and GNP: A reexamination', Journal of Energy and Development 5 (1980), pp. 326-331.

American Petroleum Institute, Petroleum Facts and Figures (New York, 5th edn, 1937).

Astorga, P., Berges, A., and Fitzgerald, V., The standard of living in Latin America during the twentieth century. Economic History Review, LVIII, 4, (2005) pp.765-796.

Bertoni, R, and Román, C., 'Estimación y análisis de la EKC para Uruguay en el siglo XX', III Simposio Latinoamericano \& Caribeño de Historia Ambiental (Carmona 2006)

Bulmer-Thomas, V., The Economic History of Latin America since Independence (Cambridge, 2003).

Carreras, A., Hofman, A., Tafunell, X. and Yañez, C. 'El desarrollo económico de América Latina en épocas de globalización- Una agenda de investigación', Estudios Estadísticos y Prospectivos, no. 24 (CEPAL. Centro de Proyecciones Económicas, 2003).

Carver, T. N., The economy of human energy (New York, 1924).

Ceselski, E., Dunkerley, J. and Ramsay, W., Household energy and the poor in the Third World (Washington D.C., 1979).

Cipolla, C. M., The Economic History of World Population (Harmondsworth, 1962).

Cipolla, C. M., Historia económica de la población mundial, (Barcelona, 1994).

Crafts., N. F. R., British economic growth during the Industrial Revolution (Oxfod, 1985).

Darmstadter, J., Teitelbaum, P. D. and Polach, J. G., Energy in the World Economy, A Statistical Review of Trends in Output, Trade and Consumption since 1925 (Baltimore, 1971).

Della Paolera, G., and Taylor, A., A new economic history of Argentina (New York 2003)

Díaz Alejandro, C.F., Essays on the Economic History of the Argentina Republic (New Haven and London, 1970)

Dunkerley, J., Ramsay, W., Gordon, L. and Ceselski, E., Energy strategies for developing nations (Baltimore, 1981).

'Editorial', in, The Times, (London, 1866), p. p.10.

Erol, U. and E.S.H.Yu. 'On the causal relationship between energy and income for industrialized countries.', Journal of Energy and Development 13 (1987), pp. 113-122.

Federico, G. and Tena, A. 'On The Accuracy Of Foreign-Trade Statistics (1909-1935) - Morgenstern Revisited', Explorations in Economic History 28, no. 3 (1991), pp. 259-273.

Folchi, M. and M. Rubio. 'El consumo aparente de energía fósil en los países latinoamericanos hacia 1925: una propuesta metodológica a partir de las estadísticas de comercio exterior', Paper presented at the Segundo Congreso Nacional de Historia Economica, Mesa temática № 6, Universidad Autonoma de Mexico 2004.

Folchi, M. and M. Rubio, 'El consumo de energía fósil y la especificidad de la transición energética en América Latina, 1900-1930', III Simposio Latinoamericano y Caribeño de Historia Ambiental, Carmona (Sevilla), April 2006

Grübler, A. 'Transition in Energy Use'. Encyclopedia of Energy, 6, (2004), pp. 163-77.

Hobson, J. A., Work and wealth: A human valuation (New York, 1914).

Hofman, A. A., The Economic Development of Latin America in the Twentieth Century (Cheltenham, UK, 2000). 
Jevons, W. S., The Coal Question (Cambridge, 1865).

Kraft, J. and A.Kraft. 'On the relationship between energy and GNP', Journal of Energy and Development 3 (1978), pp. 401-403.

Kuntz, S. 'Nuevas series del comercio exterior de México, 1870-1929', Revista de Historia Económica XX:, no. 2 (2002), pp. 213-270.

Fell, N.H., "Economic Development in Brazil, 1822-1913" in Haber, S., How Latin American Fell Behind. Essays on the Economic Histories of Brazil and Mexico, 1800-1914 (Standford, 1997).

Leff, N.H. 'Economic Development in Brazil, 1822-1913', in S. Haber, How Latin America Fell Behind. Essays on the Economic Histories of Brazil and Mexico, 1800-1914, (Stanford U.P., Standford, 1997), pp. 34-64.

Maddison, A., Monitoring The World Economy, 1820-1992 (Paris, 1995).

Maddison, A. 'Growth Accounts, Technological Change, and the Role of Energy in Western Growth', in Istituto Internazionale di Storia Economica F.Datini ed., Economia ed energia. Secoli XIII-XVIII -Atti Delle Settimane di Studi, No34--, (Florence, 2003).

Makhoul, B. O., SM. 'Exploring the accuracy of international trade statistics', Applied Economics 30, no. 12 (1998), pp. 1603-1616.

Martínez Alier, J. y. K. S., La Ecología y la Economía (México D.F., 1991).

Mitchell, B. R., International Historical Statistics - The Americas, 1750-1993 (Basingstoke, 2nd edn, 1993).

Mullen, J. W., Energy in Latin America: the historical record. Vol. S/N- E.82.II.G.14, Cuadernos de la CEPAL (Santiago de Chile, 1978).

Mumford, L., Technics and civilisation (New York, 1934).

Mumford, L., Técnica y civilización (Madrid, 1981).

Oh, W. and Lee, K. 'Causal relationship between energy consumption and GDP revisited: the case of Korea 1970 -1999', Energy Economics 26 (2004), pp. 51-59.

OxLAD. Oxford Latin American Economic History Database (OxLAD). In, Latin American Centre at the Oxford University, http://oxlad.qeh.ox.ac.uk/index.php. (accessed.

Parniczky, G. 'On the inconsistency of world trade statistics', International Statistical Review 48, no. 1 (1980), pp. 43-48.

Pérez Brignoli, H., 'The Economies of Central America, 1860-1940', in Cardenas, E., Ocampo, J.A. and Thorp, R., An economic history of twentieh-century Latin America. Vol.1. (Palgrave, Hounmills. 2000), pp. 85-117.

Read, T. T. 'The World's Output of Work', American Economic Review 23, no. 1 (1933), pp. 55-60.

Read, T. T. 'World's Output of Work', American Economic Review 35, no. 1 (1945), pp. 143-145.

Rozansky, J. and Yeats, A. 'On The (In)Accuracy Of Economic Observations - An Assessment Of Trends In The Reliability Of International-Trade Statistics', Journal of Development Economics 44, no. 1 (1994), pp. 103-130.

Rubio, M. d. M. and Folchi, M. 'Energy as an Indicator of Modernisation in Latin America by 1925', UPF Economics and Business Working Papers, No868 (2005), pp.1-37

Rubio, M. d. M. and Folchi, M. 'On the accuracy of Latin American trade statistics: a nonparametric test for 1925', UPF Economics and Business Working Papers, No879 (2005), pp.1-35.

Solow, R. M. 'The Economics of Resources or the Resources of Economics', The American Economic Review 64, no. 2 (1974), pp. 1-14.

Solow, R. M. 'Intergenerational Equity and Exhaustible Resources', Review of Economic Studies (1974), pp. 29-46.

Stern, D. and Cleveland, C. J. 'Energy and Economic Growth', Rensselaer Working Papers in Economics, no. 0410 (2004). 
Stern, D. I. 'A multivariate cointegration analysis of the role of energy in the U.S.macroeconomy', Energy Economics 22 (2000), pp. 267-283.

Stiglitz, J. 'Growth with exhaustible natural resources: efficient and optimal growth paths', Review of Economic Studies. Symposium on The Economics of Exhaustible Resources, no. 41 (1974), pp. 123137.

Summerhill, W., 'Transport Improvement an Economic Growth in Brazil and Mexico' in Haber, S., How Latin American Fell Behind. Essays on the Economic Histories of Brazil and Mexico, 1800-1914 (Standford, 1997).

Summerhill, W., 'Railroads in Imperial Brazil, 1854-1889', in J.H. Coatsword \& A.M. Taylor, Latin América and the World Economy Since 1800, (Harvard U.P. Cambridge MA,1998), pp. 383-405.

Tafunell, X., 'Nota explicativa sobre el procedimiento de estimación de la producción hidroeléctrica'(mimeo, 2006.)

Thorp, R., Progress, Poverty and Exclusion. An Economic History of Latin America in the 20th Century (New York, 1998).

Thorp, R. and Bertram, G., Peru 1890-1977. Groeth and Policy in an Open Economy (New York, 1978).

Toman, M. A. and B.Jemelkova. 'Energy and economic development: an assessment of the state of knowledge', Energy Journal 24, no. 4 (2003), pp. 93-112.

Wrigley, E. A. 'The supply of raw materials in the Industrial Revolution', Economic History Review 15, no. 1 (1962), pp. 1-16.

Wrigley, E. A., Cambio, continuidad y azar: carácter de la revolución industrial inglesa (Barcelona, 1993).

Wrigley, E. A. 'The Industrial Revolution', Document prepared for a meeting of the Energy, Pollution and Growth Network, 2003).

Yáñez, C., M.d.M Rubio and A.Carreras, 'Economic modernisation in Latin America and the Caribbean between 1890 and 1930: A view from the modern energy consumption', paper presented at the 44th Cliometics Conference (2-4 June 2006, Binghamton University, New York, USA)

Yu, E. S. H. and B.Hwang. 'The relationship between energy and GNP: Further results.', Energy Economics 6 (1984), pp. 186-190.

$\mathrm{Yu}$, E. S. H. and Choi, J.-Y. 'The causal relationship between energy and GNP: An international comparison', Journal of Energy and Development 10 (1985), pp. 249-272.

\section{Official Publications}

Argentina: Dirección General de Estadística, Anuario del comercio exterior de la República Argentina (Buenos Aires, various years).

Belgium: Ministère des Finances, Tableau annuel du commerce avec les pays étrangers (Bruxelles, various years).

Bolivia: Dirección General de Aduanas, Comercio especial de Bolivia. Exportación-Importación (La Paz, various years).

Brazil: Directoria de Estatistica Commercial, Commercio exterior do Brasil (Rio de Janeiro, variours years).

Chile: Oficina Central de Estadística, Anuario Estadístico de la República de Chile: Comercio Exterior (Valparaíso, various years).

Colombia: Departamento de Contraloría, Anuario Estadístico. Comercio Exterior (Bogotá, various years).

Costa Rica: Dirección General de Estadística, Anuario Estadístico (San José, various years).

Cuba: Secretaría de Hacienda, Comercio Exterior (La Habana, various years).

Dominican Republic: Receptoría General de Aduanas, Report of the...fiscal period.Together with summary of commerce (Washington D.C., various years).

Ecuador: Dirección General de Estadística, Comercio Exterior del Ecuador en los años... (Quito, various years). 
El Salvador: Dirección General de Estadística, Estadística comercial (San Salvador, various years).

France: Direction Générale des Douanes, Tableau générale du commerce et de la navigation (Paris,, various years).

Germany, Der Auswärtige Handel Deutschlands, (Berlin,, various years).

Guatemala: Ministerio de Hacienda y Crédito Público, Memoria de las labores del Ejecutivo en el ramo de Hacienda y Crédito Público, . (Guatemala, various years).

México: Departamento de Estadística Nacional, Anuario Estadístico: Comercio exterior y navegación (México D.F., various years).

Nicaragua: Administración de Aduanas, Memoria del Recaudador General de Aduanas y las Estadísticas del Comercio de..., (Managua,, various years).

Paraguay: Dirección General de Estadística, El comercio exterior del Paraguay (Asunción, varoius years).

Peru: Superintendencia General de Aduanas, Estadística especial del Perú (Callao, various years).

Puerto Rico: Governor of Puerto Rico, Annual Report of the Governor of Puerto Rico, Washington, Government Printing Office

United Nations. Department of Economic Affairs, World Energy Supplies in Selected years 1925-1950 (Statistical Papers, Series J. No1, New York, 1952).

United Nations. Economic Commission for Latin America, Economic Survey of Latin America 1949. Vol. UN: E/CN.12/164/Rev.1 (New York, 1951).

United Nations. Economic Commission for Latin America, Energy in Latin America. Vol. UN: E/CN.12/384/Rev.1 (Geneva, 1957).

United Nations. Economic Commission for Latin America, Latin America and the current energy problems. Vol. ST/CEPAL/CONF.50/L.2 (Santiago, 1974).

U.S. Department of Commerce, The Foreign Commerce and Navigation of the United States (Washington D.C., various years).

U.S. Department of Commerce, Commerce Year Book. Vol. II (Foreign Countries) (Washington, various years).

U.S. Department of Commerce (by J.R.Bradley), Fuel and Power in Latin America, Trade Promotion Series, No.126 (Washington, 1931).

United Kingdom: Statistical Office of the Customs and Excise Department, Annual Statement of the Trade of the United Kingdom with Foreign Countries and Britain possessions (London,, various years).

Uruguay: Dirección General de Estadística, Anuario estadístico de la República Oriental del Uruguay (Montevideo, various years).

Venezuela: Ministerio de Hacienda y Crédito Público, Estadística mercantil y marítima (Caracas, various years).

\section{NOTES}

\footnotetext{
${ }^{1}$ Cipolla, Historia económica, p.57.

${ }^{2}$ Wrigley, 'The supply of raw materials'.

${ }^{3}$ U.S.Department of Commerce, Fuel and Power, p.1.

${ }^{4}$ Only for Brazil and Uruguay, GDP yearly data are available since 1870 . For the other large or medium size economies, namely Argentina, Chile, Colombia, Mexico -with gaps-, Peru and Venezuela data series are available from the 1900s. Most Central American countries enter the list in 1920, mostly with punctual estimations rather than annual series. See Maddison, Monitoring and Thorp, Progress, Poverty and
} 
Exclusion. Yet, before 1930 very little is known of Bolivia, Cuba, Dominican Republic, Ecuador, Haiti, Panama, Paraguay, not to mention other non independent territories like Jamaica, Puerto Rico, Trinidad and Tobago, the Guiana's and some others, for which in some cases absolutely no quantitative evidence is available. Bulmer-Thomas, Economic History of Latin America provides two punctual GDP p.c. estimates for all the independent countries and Puerto Rico in 1913 and 1928. Astorga, Berges \& Fitzgerald, 'The standard of living' provide estimates every ten years without going beyond what has been mentioned. Some punctual GDP estimates for countries of the region can also be found in and Hofman, Economic Development of Latin America.

${ }^{5}$ See Carreras et al., 'El desarrollo económico de América Latina'.

${ }^{6}$ Jevons, The Coal Question.

7 'Editorial,' The Times, April 191866.

${ }^{8}$ Hobson, Work and wealth: A human valuation.; Carver, The economy of human energy.

${ }^{9}$ Read, 'The World's Output of Work'. His earlier estimates of the world's energy output were published in several journals over the previous years. A decade later he also published the estimates for 1939, see Read, 'World's Output of Work'.

${ }^{10}$ Read, 'The World's Output of Work', p.55. About the role played by fossil fuels he précised: 'about two-thirds of the work of the world is done by coal and nearly a quarter by petroleum, while water power amounts to less than one tenth'.

${ }^{11}$ Mumford, Technics and civilisation. here read from the Spanish translation Mumford, Técnica y civilización..

${ }^{12}$ Actually, Pattric Geddes, was possibly the first one to interpret history in a physical key. See Martínez Alier, La Ecología y la Economía.

${ }^{13}$ Cipolla, The Economic History here from the Spanish book Cipolla, Historia económica.

${ }^{14}$ Cipolla, Historia económica, p.57.

${ }^{15}$ Ibid, p.57.

${ }^{16}$ Ibid, p.65.

${ }^{17}$ Ibid, p.63.

${ }^{18}$ Ibid, p.79.

${ }^{19}$ Wrigley, 'The supply of raw materials'. 
${ }^{20}$ The original version in English was published in 1988. Here we use the Spanish translation Wrigley, Cambio, continuidad y azar.

${ }^{21}$ Originally in Crafts, British economic growth. The scale of the change implied by the Crafts revision was substantial. His estimates of growth rates in England between 1760 and 1831 imply that national output in 1760 must have been approximately 60 per cent larger than supposed in earlier works. Similarly, whereas Dean and Coale estimated that output per head rose by 87 per cent over this period, Crafts put the comparable figure at only 29 per cent, (tab. 2.11, p. 45). These estimates have been subsequently revised over the 1990s.

${ }^{22}$ What follows it is a summary from Wrigley, 'The Industrial Revolution'.

${ }^{23}$ Maddison, 'Growth Accounts'.

${ }^{24}$ On the first aspect, see the survey by Toman and B.Jemelkova, 'Energy and economic development' on the second issue see, for instance Solow, 'The Economics of Resources', Solow, 'Intergenerational Equity and Exhaustible Resources'. Stiglitz, 'Growth with exhaustible natural resources'.

${ }^{25}$ On the first aspect, see the survey by Toman and B.Jemelkova 'Energy and economic development' on the second issue see, for instance Solow 'The Economics of Resources'; Solow, 'Intergenerational Equity and Exhaustible Resources' or Stiglitz 'Growth with exhaustible natural resources'.

${ }^{26}$ There are a flotilla of papers on the issue: Kraft and A.Kraft, 'On the relationship between energy and GNP'; Akarca and T.Long ‘...A reexamination'; Yu and B.Hwang, '...Further results'; Yu and Choi, '...An international comparison'; Erol and E.S.H.Yu '...energy and income for industrialized countries'; Abosedra and H.Baghestani, 'New evidence'.

${ }^{27}$ Stern and Cleveland, 'Energy and Economic Growth'

${ }^{28}$ Stern 'A multivariate cointegration analysis of the role of energy'; Oh and Lee 'Causal relationship between energy consumption and GDP'.

${ }^{29}$ Grübler, 'Transition in Energy Use'

${ }^{30}$ U.S.Department of Commerce, Fuel and Power, p.1.

${ }^{31}$ The list of countries includes Argentina, Brazil, Bolivia, Chile, Colombia, Costa Rica, Cuba, Ecuador, Guatemala, Honduras, the Guayanas, Honduras, Mexico, Nicaragua, Panama, Peru, Porto Rico,

Dominican Republic, Salvador, Uruguay, Paraguay, Venezuela, and some of the Caribbean (British, Dutch and, French West Indies plus the Virgin Islands)

${ }^{32}$ U.S.Department of Commerce, Fuel and Power, p.44.

${ }^{33}$ Read, 'The World's Output of Work', p.56.

${ }^{34}$ Ibid, p.144. Although coal data for Argentina could not be gathered for 1939 according to the author. 
${ }^{35}$ ECLA, Economic Survey 1949.

${ }^{36}$ ECLA, Energy in Latin America, p.3.

${ }^{37}$ Ibid, p.3.

${ }^{38}$ Ibid, p.6.

${ }^{39}$ Ibid, p.10.

${ }^{40}$ For instance, in the case of Argentina, the data provided by the study includes the elaborated from 1925 by the Argentine Committee to the World Energy Conference and the Instituto de Estudios Económicos del Transporte, and from 1944 the Dirección Nacional de Energía (energy body of the government).

${ }^{41} \mathrm{UN}$, World Energy Supplies. Issued annually since 1952, it is the most regular and comprehensive of the publications of international bodies dedicated to energy. By using successive editions of it, it is possible to construct a limited set of statistical series for the years 1929, 1927 and annually from 1949. According to Darmstadter 'in doing so, one must allow for fairly significant breaks in historical continuity of the data, for changes in geographic classifications, and for limitations in the scope of particular energy series' Darmstadter et al., Energy in the World Economy, p.826.

${ }^{42}$ Darmstadter et al., Energy in the World Economy.

${ }^{43}$ A t third source, also third party, was used for some early estimates: Rudolf Regul, Energiequellen der Welt, (Hamburg: Hanseatische Verlagsanstalt, 1937). For the specification of sources see Darmstadter et al., Energy in the World Economy, pp.835-859.

${ }^{44}$ Although the oil crisis in the mid 1970s compelled the research agenda to include energy issues, none of the works produced thereafter made any effort to improve the historical data series already mentioned. In 1974 the ECLA reacted to the changing oil markets and the ill effects on the Latin American economies with a symposium ECLA, Latin America and the current energy problems. The resulting volume is a compilation of articles reviewing different aspects of energy in the region, from supplies of primary and secondary energies, to the economic and financial impacts of the surging oil prices, ending with possible strategies and action programs to overcome the crisis. The statistical evidence provided was scarce and did not extend before 1960. The relevance of the volume comes from the Latin American perspective on the energy problem. Another example is the work of J.W. Mullen, which has a misleading title: Energy in Latin America; the historical record since the period considered is relatively short, 1950-75, and no continuous series are provided except the decennial bench-marks 1950, 1960 and 1970. It can hardly be 
considered an historical analysis; even so, it proposed a synoptic view that can be of interest regarding the evolution and characteristics of the main energy sectors, especially petroleum.

${ }^{45}$ We have been able to estimate annual series for 30 out of 33 .

${ }^{46}$ Domestic and foreign sources are listed in Table 1. Exchange rates were taken from U.S. Department of Commerce, Commerce Year Book.

${ }^{47}$ Although none of the domestic sources of the Caribbean had been checked, from the United States reports it is clear that these countries were captive of the United States from the coal mining strikes in the United Kingdom in the first decades of the twentieth century.

${ }^{48}$ A detailed discussion these issues can be found in Folchi and Rubio, 'El consumo aparente de energía fósil'. Specifically for the second issue see Rubio and Folchi, 'On the accuracy of Latin American trade statistics'.

${ }^{49}$ See, for instance, Makhoul, 'Exploring the accuracy of international trade statistics'; Parniczky, 'On the inconsistency of world trade statistics' and Rozansky and Yeats, 'On The (In)Accuracy Of Economic Observations'.

${ }^{50}$ Federico and Tena, 'On The Accuracy Of Foreign-Trade Statistics'.

${ }^{51}$ Kuntz, 'Nuevas series'.

${ }^{52}$ The Colombian case is actually better off in the absolute comparison. The explanation lies in the imports reported as from Costa Rica in the Colombian trade statistics. This is very likely to be oil from the United States in fact, and so it shows in the United States Department of Commerce figures.

${ }^{53}$ See Rubio and Folchi, 'On the accuracy of Latin American trade statistics'. In this paper the Wilcoxon Matched-Pairs Ranks test is used to determine whether the differences between the data registered by exporters and importers are meaningful, and if so, whether the differences are systematic in any direction.

${ }^{54}$ Coal production was taken from Mitchell, Historical Statistics.

${ }^{55}$ Oil production obtained from the American Petroleum Institute, Petroleum Facts and Figures.

${ }^{56}$ American Petroleum Institute, Petroleum Facts and Figures, p.116.

${ }^{57}$ Over the 1920s the cracking process will minimise the refining losses progressively. That explains why in present estimates no allowance is made for the refining losses when estimating home consumption of oil producers.

${ }^{58}$ In the most extreme case, Mexico, where refined products accounted for $40 \%$ of the exports, the adjustment due to the losses in refining amounted to some 390 thousand tons of crude oil. That is much 
more of the oil imports of most of the countries of the region and represented some extra $25 \mathrm{~kg}$ of oil for each of the 15 million Mexican. For the precise adjustments see Cuadro 4.1.10 in Folchi and Rubio, 'El consumo aparente'.

${ }^{59}$ On the issue of the exceptional early transition from coal to oil of the Latin American countries see Folchi and Rubio, '...la especificidad de la transición energética en América Latina’.

${ }^{60} \mathrm{We}$ are indebted to Xavier Tafunell for sharing with us his estimations of hydroelectricity. He tested the results of this estimation with the little available information and the results gave us all confidence in using his figures of hydropower. For a short discussion of the method and results see Tafunell, X., 2006. 'Nota explicativa sobre el procedimiento de estimación de la producción hidroeléctrica' (mimeo,)

${ }^{61}$ This and the following section rely almost entirely on Yañez et alt 'Economic modernisation'.

${ }^{62}$ Díaz Alejandro, Essays; Della Paolera \& Taylor, A new economic history.

${ }^{63}$ By 1905, on an average round trip Liverpool-New York consumed 5,000 Tons of coal, therefore few misallocated ships bunkering would make a great difference for Uruguayan energy consumption per capita. A recent research paper by Bertoni and Roman, ‘Estimación y análisis' re-estimated downwards the Uruguayan energy consumption taking bunkering into account, which still remains among the highest in the continent.

${ }^{64}$ Peruvian production started in 1896, exports in 1897; Mexican production began in 1901, but meaningful exports only began in 1911; Argentinean oil was first found in sufficient amounts in 1908, with some very small exports from 1915; Trinidad \& Tobago commercial oil production began in 1909, exporting almost entirely to the UK from 1911; Venezuela and Ecuador official start of oil production is 1917, but the War delayed exports until 1920 in the first case and 1925 in the second; Colombia first reported production is from 1922 and export in 1926. 'Together they amounted to 15 per cent of the world's petroleum output, while the United States represented 72 per cent. In other words, Latin America extracted more than half of the petroleum obtained outside the United States' Rubio and Folchi, 'Energy as Indicator', p.13

${ }^{65}$ Leff, 'Economic Development'; Summerhill, 'Transport' and Summerhill, 'Railroads”.

${ }^{66}$ Thorp and Bertram, Peru.

${ }^{67}$ Pérez Brignoli, 'Central America'

${ }^{68}$ Plus other scarcely populated territories like British Honduras (-26.1) and French Guiana (-15.0) 


\section{TABLES}

Table 1

Coal trade patterns: countries of origin of Latin American coal imports in 1925

(15 countries, in tonnes)

\begin{tabular}{|c|c|c|c|c|c|c|}
\hline \multirow{3}{*}{ Country } & \multirow{2}{*}{$\begin{array}{c}\text { Total } \\
\text { Coal } \\
\text { Imports }\end{array}$} & \multicolumn{5}{|c|}{$\begin{array}{l}\text { Main countries of origin } \\
\text { er all petroleum products imported }\end{array}$} \\
\hline & & UK & US & Germany & $\begin{array}{c}\text { Total } \\
\text { G3 }\end{array}$ & Others \\
\hline & Tonnes & $\%$ & $\%$ & $\%$ & $\%$ & $\%$ \\
\hline Argentina & 3.178 .473 & 87 & 5 & 6 & 98 & 2.10 \\
\hline Bolivia & 15.709 & 29 & 6 & 3 & 39 & 61 \\
\hline Brazil & 1.727 .050 & 63 & 36 & 0.03 & 99 & 0.81 \\
\hline Chile & 264.070 & 79 & 14 & 2 & 96 & 3.78 \\
\hline Colombia & 3.263 & 49 & 50 & 0 & 99 & 0.35 \\
\hline Costa Rica & 808 & 39 & 61 & 0 & 100 & 0 \\
\hline Cuba & 659.389 & 1 & 99 & 0 & 100 & 0 \\
\hline Dominican R. & 9.764 & 0 & 99 & 0 & 99 & 0.69 \\
\hline Ecuador & 1.278 & 6 & 86 & 1 & 93 & 7.12 \\
\hline El Salvador & 154 & 0 & 100 & 0 & 100 & 0 \\
\hline Guatemala & 264 & 00 & 100 & 0 & 100 & 0 \\
\hline Haití & 156 & 0 & 100 & 0 & 100 & 0 \\
\hline México & 65.845 & 1 & 99 & 0.07 & 99.85 & 0.15 \\
\hline Nicaragua & 2.646 & 13 & 86 & 0 & 100 & 0 \\
\hline Peru & 39.235 & 45 & 45 & 7 & 97 & 2.16 \\
\hline TOTAL & 5.968 .104 & 69 & 26 & 3 & 98 & 1.72 \\
\hline
\end{tabular}

Sources: Domestic sources, as listed at the Appendix: data sources.

NOTES: Chile was Bolivia's main suppliers with 9.317 tonnes, this is $59,3 \%$ of Bolivia imports. Other suppliers to Argentina and Chile were Australia (9.103 tonnes to Chile), Holland (55.084 tonnes to Argentina and Chile) and Chilean coal to Argentina (8.843 tonnes). 
Table 2

Petroleum trade patterns: origin of Latin American petroleum imports in 1925

\begin{tabular}{|c|c|c|c|c|c|c|}
\hline \multirow{3}{*}{ Countries } & \multicolumn{6}{|c|}{$\begin{array}{l}\text { Main countries of origin } \\
\text { (\% over all petroleum products imported })\end{array}$} \\
\hline & $\begin{array}{l}\text { Petroleum } \\
\text { Imports }\end{array}$ & US & Mexico & Peru & Others & $\begin{array}{l}\text { Main } \\
\text { countries } \\
\text { of origins }\end{array}$ \\
\hline & Tonnes & $\%$ & $\%$ & $\%$ & $\%$ & $\%$ \\
\hline Argentina & 689.207 & 39 & 30 & 29 & & 98 \\
\hline Bolivia (a) & 22.593 & 32 & & 9 & 54 & 95 \\
\hline Brazil & 508.814 & 41 & 58 & & & 99 \\
\hline Colombia (b) & 9.600 & 37 & & 5 & 48 & 90 \\
\hline Chile & 906.661 & 77 & 13 & 10 & & 100 \\
\hline Costa Rica (c) & 47.272 & 3 & 79 & 3 & 15 & 100 \\
\hline Cuba & 1.284 .027 & 30 & 69 & & & 100 \\
\hline Dominican Rep. & 37.649 & 42 & 26 & & 16 & 84 \\
\hline Ecuador & 13.100 & 12 & & 88 & & 100 \\
\hline El Salvador & 22.549 & 88 & & 12 & & 100 \\
\hline Guatemala & 68.458 & 45 & 50 & 4 & & 99 \\
\hline Haiti (d) & 6.113 & 72 & & & 17 & 89 \\
\hline Mexico & 366.451 & 99 & & & & 99 \\
\hline Nicaragua & 14.648 & 49 & 32 & 19 & & 100 \\
\hline Peru (e) & 8.084 & 92 & & & 6 & 98 \\
\hline TOTAL & 4.005 .226 & 51 & 40 & 8 & 1 & 99 \\
\hline
\end{tabular}

Sources: Domestic sources, as listed at the Appendix: data sources.

NOTES:

(a) Other $=$ Chile

(b) Other = Costa Rica (Colombia reports 4.500 tonnes of gasoline from Costa Rica)

(c) Other = Panama

(d) Other = Curaçao (Venezuelan oil), the remaining 10\% from Panama and Puerto Rico in equal share

(e) Other = Unites Kingdom

Other = Puerto Rico; also the Dutch West Indies are responsible for a similar percentage 
Table 3

Imports of coal in Latin America by 1925, quantities

Difference between importers and exporters registries

\begin{tabular}{|c|c|c|c|c|c|}
\hline \multirow[b]{2}{*}{ Country } & \multicolumn{2}{|c|}{ Metric tonnes } & \multicolumn{3}{|c|}{ Difference \% } \\
\hline & $\begin{array}{l}\text { Source } \\
\text { importers }\end{array}$ & $\begin{array}{c}\text { Source } \\
\text { exporters }\end{array}$ & $\begin{array}{c}\text { I-E } \\
\text { tonnes }\end{array}$ & $(I-E) / I$ & $(E-I) / E$ \\
\hline Argentina & 3.111 .979 & 2.925 .091 & 186.888 & 6.01 & -6.39 \\
\hline Bolivia & 6.077 & 664 & 5.413 & 89.07 & -814.78 \\
\hline Brazil & 1.715 .203 & 1.814 .136 & -98.933 & -5.77 & 5.45 \\
\hline Chile & 253.554 & 195.197 & 58.357 & 23.02 & -29.90 \\
\hline Colombia & 3.252 & 3.125 & 127 & 3.92 & -4.08 \\
\hline Costa Rica & 808 & 78 & 730 & 90.32 & -933.05 \\
\hline Cuba & 659.389 & 701.707 & -42.318 & -6.42 & 6.03 \\
\hline Dominican Rep. & 9.697 & 9.484 & 213 & 2.19 & -2.24 \\
\hline Ecuador & 1.187 & 1.131 & 56 & 4.77 & -5.01 \\
\hline El Salvador & 154 & 113 & 41 & 26.78 & -36.57 \\
\hline Guatemala & 264 & 3.287 & -3.023 & -1.144 .81 & 91.97 \\
\hline Haiti & 156 & 83 & 73 & 46.44 & -86.71 \\
\hline Mexico & 65.746 & 118.643 & -52.897 & -80.46 & 44.59 \\
\hline Nicaragua & 2.646 & 2.476 & 170 & 6.42 & -6.87 \\
\hline Peru & 38.389 & 32.542 & 5.847 & 15.23 & -17.97 \\
\hline TOTAL & 5.868 .500 & 5.807 .758 & 60.746 & 1.0 & -1.0 \\
\hline
\end{tabular}

Sources: as listed at the Appendix of data sources. 
Table 4

Absolute and Comparable imports of petroleum products in 1925 data (contrast of domestic and foreign sources)

\begin{tabular}{|c|c|c|c|c|c|c|}
\hline \multirow[b]{2}{*}{ Importer } & \multicolumn{3}{|c|}{ A) Absolute total imports of petroleum products } & \multicolumn{3}{|c|}{ B) Comparable total imports petroleum products } \\
\hline & $\begin{array}{c}\text { Tonnes } \\
\text { imported } \\
\text { (domestic } \\
\text { source) } \\
\text { A }\end{array}$ & $\begin{array}{c}\text { Tonnes } \\
\text { imported } \\
\text { (country of } \\
\text { origin source) } \\
\text { B }\end{array}$ & $\begin{array}{c}\text { Quantitative } \\
\text { differences } \\
\text { (A-B)/A } \\
\% \\
\text { C }\end{array}$ & $\begin{array}{c}\text { Tonnes imported } \\
\text { (domestic source) } \\
\text { D }\end{array}$ & $\begin{array}{c}\text { Tonnes } \\
\text { imported } \\
\text { (country of } \\
\text { origin source) } \\
\text { E }\end{array}$ & $\begin{array}{c}\text { Quantitative } \\
\text { differences } \\
(\mathrm{E}-\mathrm{F}) / \mathrm{E} \\
\% \\
\mathrm{~F}\end{array}$ \\
\hline Argentina & 688.026 & 670.109 & 3 & 677.196 & 670.109 & 1 \\
\hline Bolivia & 22.027 & 18.227 & 17 & 21.498 & 18.227 & 15 \\
\hline Brazil & 505.753 & 552.147 & -9 & 505.753 & 552.147 & -9 \\
\hline Chile & 906.641 & 923.112 & -2 & 906.540 & 923.112 & -2 \\
\hline Colombia & 9.232 & 11.888 & -29 & 4.410 & 11.888 & -170 \\
\hline Costa Rica & 47.272 & 36.799 & 22 & 40.275 & 36.799 & 9 \\
\hline Cuba & 1.281949 & 1.352 .397 & -5 & 1.281 .942 & 1.352 .397 & -5 \\
\hline Dominican R. & 41.983 & 46.908 & -12 & 30.784 & 46.908 & -52 \\
\hline Ecuador & 13.100 & 27.838 & -113 & 13.015 & 27.838 & -114 \\
\hline El Salvador & 22.549 & 12.072 & 46 & 22.536 & 12.072 & 46 \\
\hline Guatemala & 68.247 & 50.794 & 26 & 68.151 & 50.794 & 25 \\
\hline Haití & 7.141 & 5.165 & 28 & 5.446 & 5.165 & 5 \\
\hline Honduras & & 107.916 & & & & \\
\hline México & 361.448 & 324.330 & 10 & 361.438 & 324.330 & 10 \\
\hline Nicaragua & 14.643 & 11.639 & 21 & 9.958 & 11.639 & -17 \\
\hline Panama & & 832.308 & & & & \\
\hline Paraguay & & 197 & & & & \\
\hline Peru & 8.006 & 6.743 & 16 & 7.443 & 6.743 & 9 \\
\hline Uruguay & 226.045 & 183.686 & 19 & & & \\
\hline Venezuela & 2.287 & 14.021 & -513 & & & \\
\hline $\begin{array}{l}\text { Bermuda } \\
\text { Br. Honduras }\end{array}$ & & $\begin{array}{l}8.910 \\
2.967\end{array}$ & & & & \\
\hline Barbados & & 712 & & & & \\
\hline Jamaica & & 7.423 & & & & \\
\hline T. \& Tobago & & 1.154 & & & & \\
\hline British W.I.I. & & 85.452 & & & & \\
\hline Danish W.I.I. & & 35.370 & & & & \\
\hline Dutch W.I.I. & & 3.931 & & & & \\
\hline French W.I.I. & & 2.506 & & & & \\
\hline British Guiana & & 542 & & & & \\
\hline French Guiana & & 350 & & & & \\
\hline Dutch Guiana & & 1.537 & & & & \\
\hline Puerto Rico & & 58.784 & & & & \\
\hline LA (17) & 4.226 .350 & 4.247 .873 & $\overline{-1}$ & 3.956 .383 & 4.050 .166 & -2 \\
\hline LA (33) & & 5.339 .148 & & & & \\
\hline
\end{tabular}

Sources: Domestic sources, as listed at the Appendix: data sources.

Two types of blank data,1) the source did not report imports/exports to that country; 2) the source was not available (that is the whole Caribbean, Honduras, Panama) or it was unsuitable to identify origins (Paraguay, Uruguay and Venezuela).

A negative sign in the differences means that tonnes are missing from the importer reports A positive sign in the differences implies that tonnes are reported in excess by the importer 
Table 5

Old and new estimates of apparent consumption of fossil fuels per capita for Latin America in 1925

(tonnes of oil equivalent per 1000 habitants)

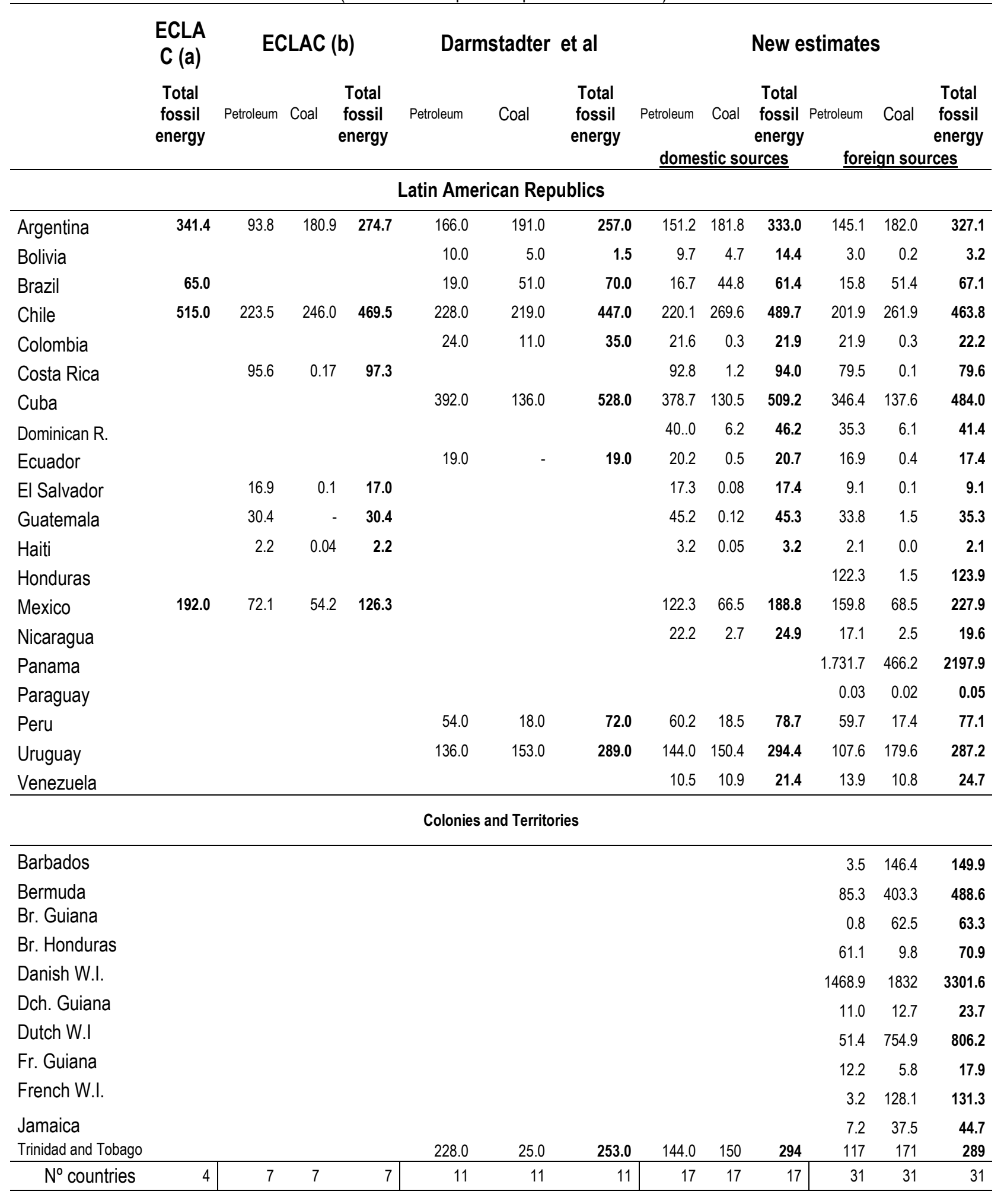

Notes: ECLA (a) estimates for year 1925 in ECLA (1951); ECLA (b) estimates for year 1925 in ECLA (1957); Darmstadter et al (1971) 
Table 6

Levels of modern energy consumption per capita in Latin America and the Caribbean Ranking for years 1890, 1900, 1913 and 1925

\begin{tabular}{|c|c|c|c|c|c|c|c|}
\hline \multicolumn{2}{|c|}{1890} & \multicolumn{2}{|c|}{1900} & \multicolumn{2}{|c|}{1913} & \multicolumn{2}{|c|}{1925} \\
\hline Country & TOE/cap.* & Country & TOE/cap. * & Country & TOE/cap. ${ }^{*}$ & Country & TOE/cap.* \\
\hline \multicolumn{8}{|c|}{ Latin American Republics } \\
\hline Uruguay & 278.6 & Uruguay & 360.3 & Panama & 1.276 .4 & Panama & 2.197 .9 \\
\hline Chile & 171.5 & Chile & 189.5 & Chile & 503.8 & Chile & 490.3 \\
\hline Argentina & 116.9 & Cuba & 158.3 & Uruguay & 449.8 & Cuba & 484.0 \\
\hline Cuba** $^{* *}$ & 114.3 & Argentina & 122.9 & Cuba & 391.7 & Argentina & 331.0 \\
\hline A.L. \& C. & 44.3 & México & 70.6 & Argentina & 335.0 & Uruguay & 287.2 \\
\hline Brazil & 33.3 & A.L. \& C. & 63,4 & A.L. \& C & 142.9 & Mexico & 251.6 \\
\hline Peru & 17.3 & Brazil & 34.5 & México & 111.1 & A.L. \& C. & 176.9 \\
\hline Puerto Rico** & 16.2 & Peru & 27.5 & Peru & 91.4 & Honduras & 127.5 \\
\hline Costa Rica & 13.3 & Costa Rica & 26.4 & Costa Rica & 89.3 & Costa Rica & 113.6 \\
\hline Venezuela & 11.6 & Puerto Rico & 16,9 & Brazil & 76.7 & Peru & 89.6 \\
\hline Nicaragua & 10.4 & Dominican $\mathrm{R}$. & 8,3 & Puerto Rico & 26.1 & Brazil & 75.1 \\
\hline México & 10.1 & Nicaragua & 6.4 & Guatemala & 24.1 & Puerto Rico & 55.6 \\
\hline Colombia & 8.7 & Colombia & 5.5 & Dominican $\mathrm{R}$. & 16.9 & Dominican $\mathrm{R}$. & 41.4 \\
\hline Dominican $\mathrm{R}$. & 5.8 & Venezuela & 5.5 & Honduras & 11.2 & Guatemala & 39.5 \\
\hline Haiti & 3.1 & Haiti & 3.0 & Ecuador & 10.2 & Colombia & 26.5 \\
\hline Honduras & 0.8 & Honduras & 2.8 & Nicaragua & 9.7 & Venezuela & 26.4 \\
\hline Ecuador & 0.5 & Guatemala & 1.5 & Venezuela & 9.2 & Ecuador & 21.1 \\
\hline El Salvador & 0.4 & Ecuador & 0,9 & Haiti & 5.4 & Nicaragua & 19.6 \\
\hline \multirow[t]{2}{*}{ Guatemala } & 0.4 & El Salvador & 0.5 & Colombia & 3.4 & El Salvador & 12.6 \\
\hline & & & & El Salvador & 1.9 & Haiti & 2.1 \\
\hline \multicolumn{8}{|c|}{ Colonies and territories } \\
\hline Bermuda & 353.7 & Danish W.I. & 1.543 .5 & Danish W.I. & 2.700 .0 & Danish W.I. & 3.301 .6 \\
\hline Br. Guiana & 208.0 & Bermuda & 1.075 .2 & Dutch W.I & 784.1 & Dutch W.I & 806.2 \\
\hline \multirow[t]{9}{*}{$\mathrm{Br}$. Honduras } & 9.8 & French W.I & 82.2 & Bermuda & 572.5 & Bermuda & 488.6 \\
\hline & & Dutch W.I & 74.1 & Trinidad \& T. & 484.6 & Trinidad \& T. & 289.0 \\
\hline & & Br. Guiana & 65.2 & Barbados & 289.1 & Barbados & 149.9 \\
\hline & & Dch. Guiana & 49.9 & $\mathrm{Br}$. Honduras & 106.2 & French W.I. & 131.3 \\
\hline & & Br. Honduras & 28.8 & French W.I. & 83.0 & Br. Honduras & 70.9 \\
\hline & & & & Br. Guiana & 73.5 & Br. Guiana & 63.3 \\
\hline & & & & Dch. Guiana & 57.9 & Jamaica & 44.7 \\
\hline & & & & Jamaica & 50.4 & Dch. Guiana & 23.7 \\
\hline & & & & Fr. Guiana & 27.3 & Fr. Guiana & 17.9 \\
\hline \multicolumn{8}{|c|}{ Pro memoria: United States and Spain } \\
\hline United States & 3.571 .6 & United States & 4.913 .2 & United States & 7.869 .8 & United States & 8.889 .9 \\
\hline Spain & 123.0 & Spain & 194.2 & Spain & 274.3 & Spain & 255.1 \\
\hline
\end{tabular}

Notes: TOE: Tonnes of oil equivalent. ${ }^{*} \mathrm{TOE} / \mathrm{cap}$ are actually TOE per 1000 habitants. ${ }^{* *} \mathrm{Cuba}$ and Puerto Rico were Spanish colonies up to 1898 . The former obtained independence in 1902, the latter remained under US influence till today. Modern energy includes fossil plus hydroelectric consumption.

Sources quoted at the Appendix: data sources. 
Table 7

Rates of growth of per capita modern energy consumption (\%)

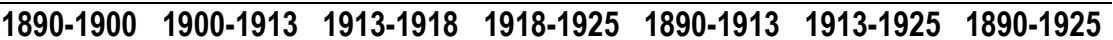

\begin{tabular}{|c|c|c|c|c|c|c|c|}
\hline \multicolumn{8}{|c|}{ Latin American Republics } \\
\hline Argentina & 0.5 & 8.0 & -29.0 & 26.4 & 4.7 & -0.6 & 2.8 \\
\hline Brazil & 0.4 & 6.3 & -15.6 & 12.6 & 3.7 & -0.2 & 2.4 \\
\hline Chile & 1.0 & 7.8 & -5.3 & 3.3. & 4.8 & -0.4 & 3.0 \\
\hline Colombia & -4.4 & -3.7 & -5.1 & 39.1 & -4.0 & 18.6 & 3.2 \\
\hline Costa Rica & 7.1 & 9.8 & -23.8 & 25.2 & 8.6 & 1.8 & 6.2 \\
\hline Cuba & 3.3 & 7.2 & -0.1 & 3.1 & 5.5 & 1.8 & 4.2 \\
\hline Dominican Republic & 3.6 & 5.6 & 13.6 & 3.7 & 4.8 & 7.8 & 5.8 \\
\hline Ecuador & 5.9 & 21.0 & -3.6 & 8.1 & 14.2 & 3.1 & 10.3 \\
\hline El Salvador & 0.8 & 11.8 & 12.9 & 17.5 & 6.9 & 15.6 & 9.8 \\
\hline Guatemala & 15.2 & 24.1 & -33.0 & 42.2 & 20.1 & 4.0 & 14.3 \\
\hline Haiti & -0.3 & 4.6 & -17.2 & 0.0 & 2.4 & -7.6 & -1.1 \\
\hline Honduras & 13.9 & 11.3 & 24.7 & 20.9 & 12.4 & 22.5 & 15.8 \\
\hline Mexico & 21.4 & 3.6 & 11.5 & 4.0 & 11.0 & 7.1 & 9.6 \\
\hline Nicaragua & -4.7 & 3.3 & 18.6 & -5.1 & -0.3 & 4.1 & 1.2 \\
\hline Panama & & & -3.2 & 10.4 & & 4.5 & \\
\hline Peru & 4.7 & 9.7 & 1.3 & -1.2 & 7.5 & -0.2 & 4.8 \\
\hline Puerto Rico & 0.4 & 3.4 & & & 2.1 & 6.5 & 3.6 \\
\hline Uruguay & 2.4 & 1.9 & -14.5 & 7.3 & 2.1 & -2.4 & 0.5 \\
\hline Venezuela & -7.1 & 4.0 & 12.0 & 10.6 & -1.0 & 9.2 & 2.4 \\
\hline \multicolumn{8}{|c|}{ Colonies and territories } \\
\hline Barbados & & & -1.5 & -8.0 & & -5.3 & \\
\hline Bermuda & 11.8 & -4.7 & 9.0 & -8.1 & 2.1 & -1.3 & 0.9 \\
\hline British Guiana & -11.0 & 0.9 & -2.5 & -0.4 & -4.4 & -1.2 & -3.3 \\
\hline British Honduras & 11.3 & 10.6 & -26.1 & 17.2 & 10.9 & -3.3 & 5.8 \\
\hline French Guiana & & & -15.0 & 5.8 & & -3.4 & \\
\hline Jamaica & & & -14.5 & 9.9 & & -1.0 & \\
\hline Trinidad and Tobago & & & 3.2 & 6.3 & & 5.0 & \\
\hline LATIN AMERICA & 3.6 & 6.4 & -6.2 & 8.1 & 5.1 & 1.8 & 4.0 \\
\hline \multicolumn{8}{|c|}{ Pro memoria: United States and Spain } \\
\hline United Status & 3.2 & 3.7 & & & 3.5 & 1.0 & 2.6 \\
\hline Spain & 4.7 & 2.7 & & & 3.5 & -0.6 & 2.1 \\
\hline
\end{tabular}

Sources quoted at the Appendix of data sources. 


\section{FIGURES}

Figure 1

Modern energy per capita (coal, oil \& hydroelectricity) vs GDP per capita in Latin American countries, 1937

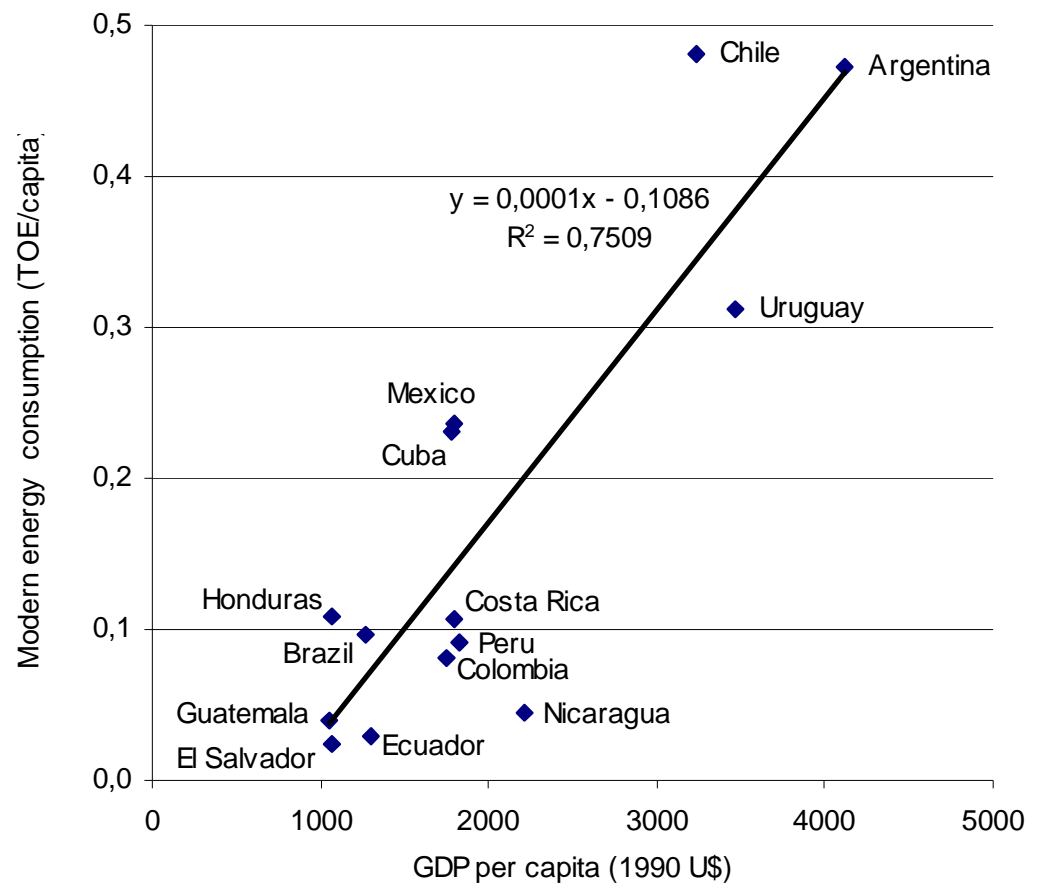

Sources: Modern energy data from ECLAC (1956), GDP from Maddison (2003). Brazil data is for 1939.

Figure 2

Ratio of organic energy consumption on total energy consumption and GDP per capita for Latin American countries, 1937

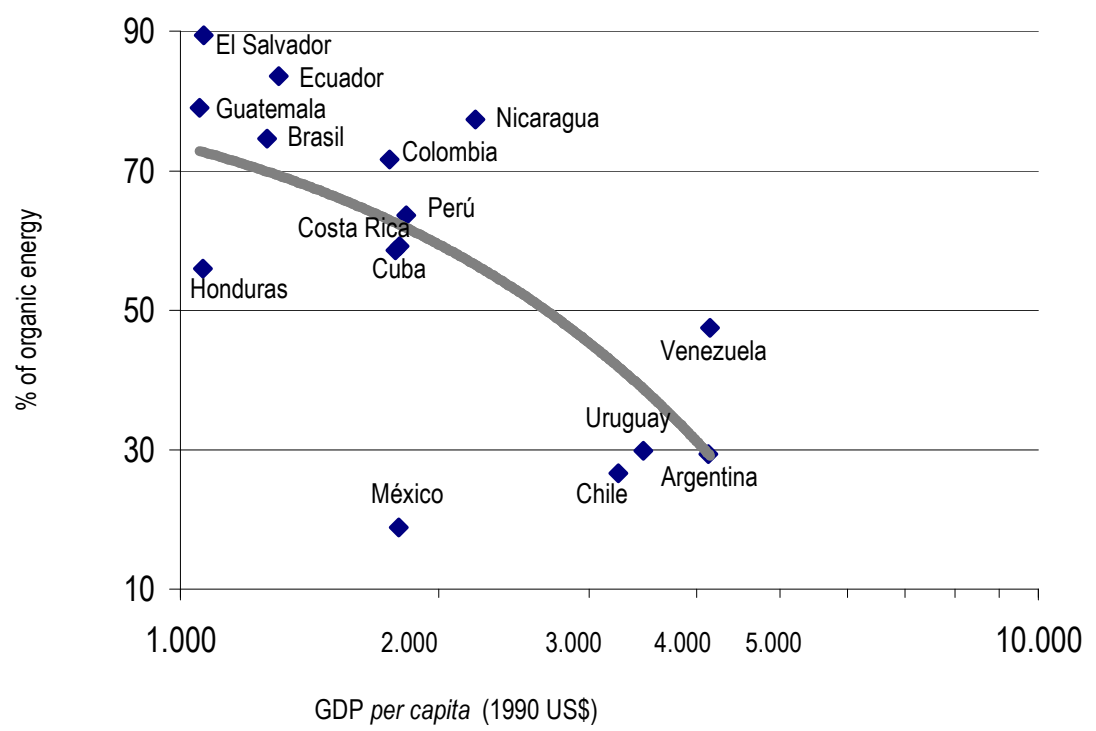

Source: Folchi M. and Rubio, M.d.M. (2006) 
Figure 3

Tonnes of oil equivalent per 1000 habitants by country (Argentina, Chile, Cuba and Uruguay)

Argentina, Chile, Cuba, Panama \& Uruguay, 1890-1925

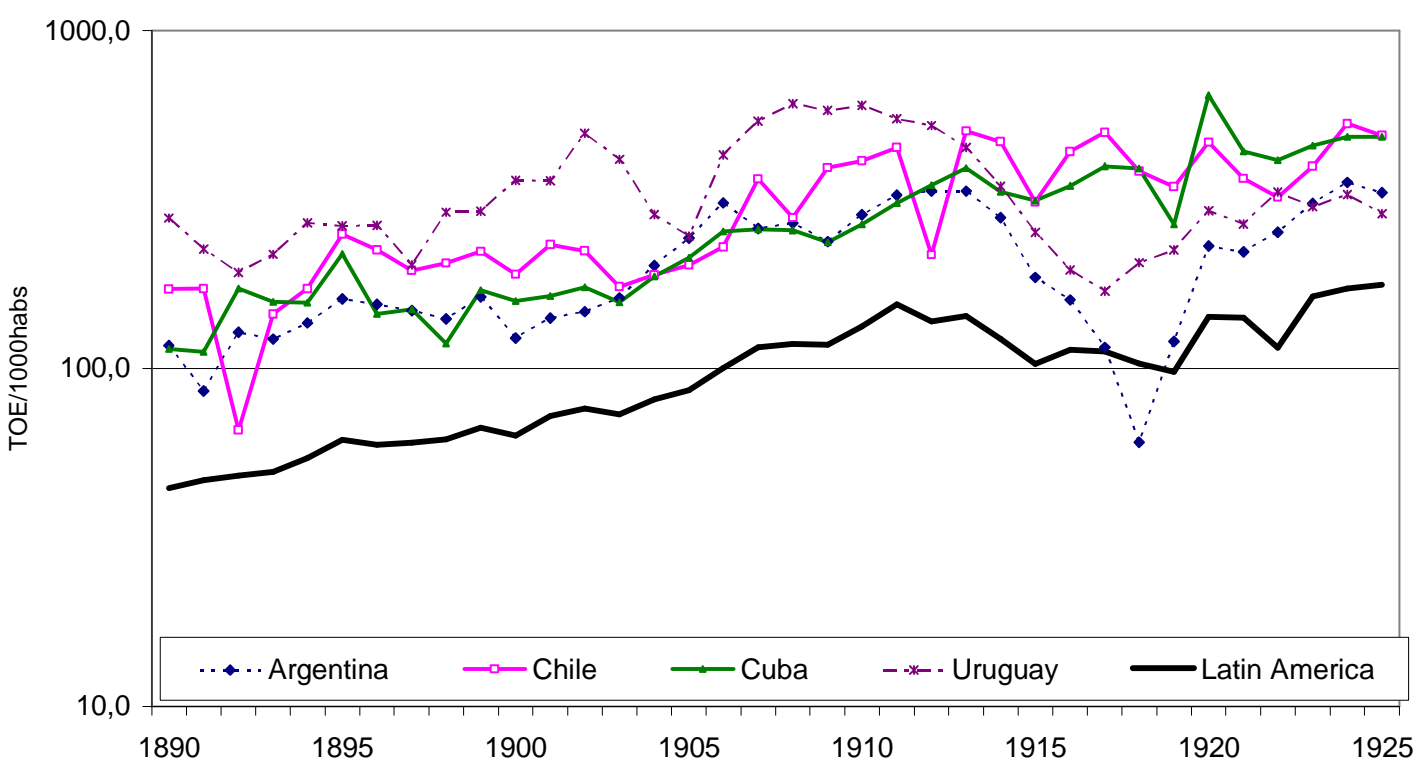

Source: Appendix of data sources

Figure 4

Tonnes of oil equivalent per 1000 habitants by country (Brazil, Mexico and Peru)

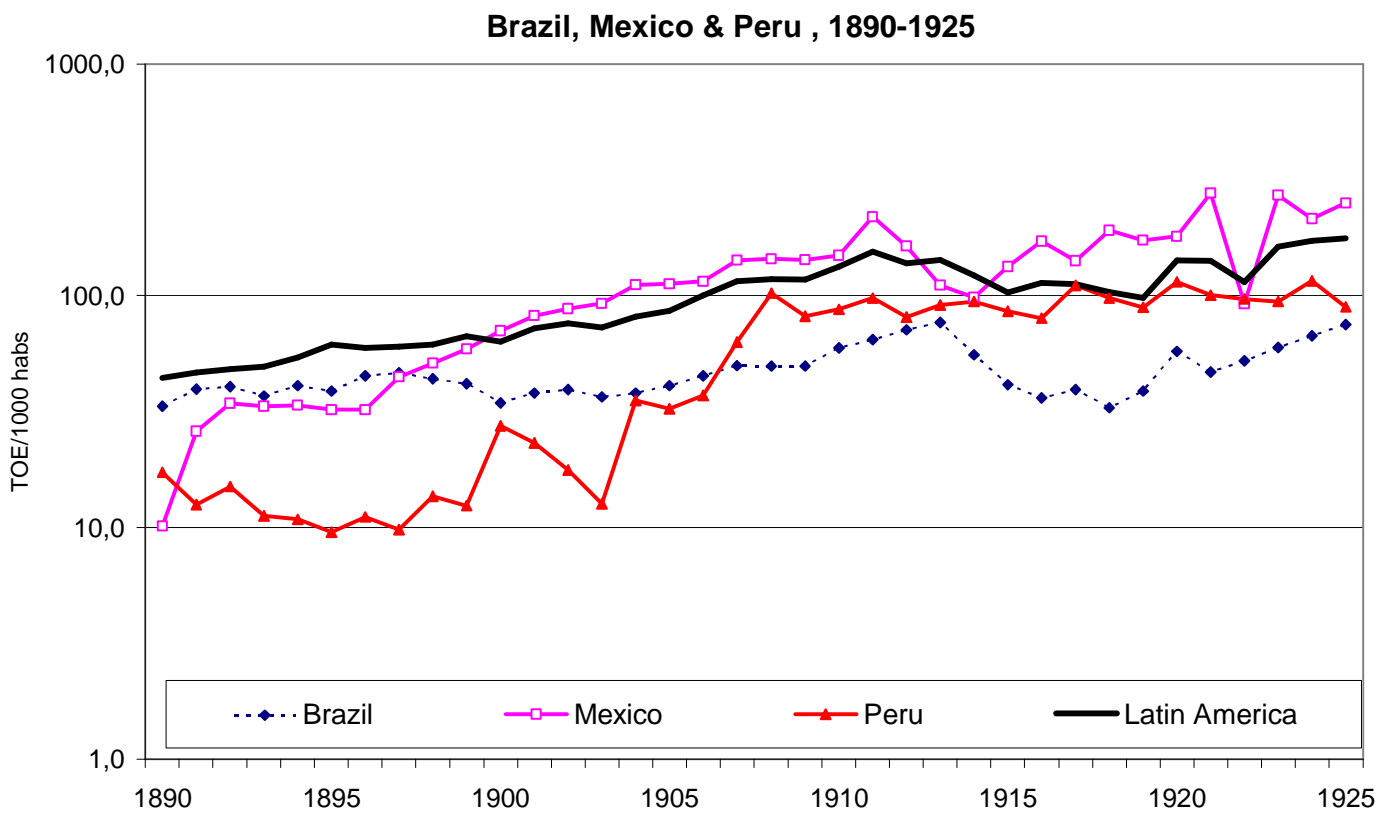

Source: Appendix of data sources 
Figure 5

Tonnes of oil equivalent per 1000 habitants by country

(Colombia, Panama, Ecuador y Venezuela)

Colombia, Panama, Ecuador y Venezuela, 1890-1925

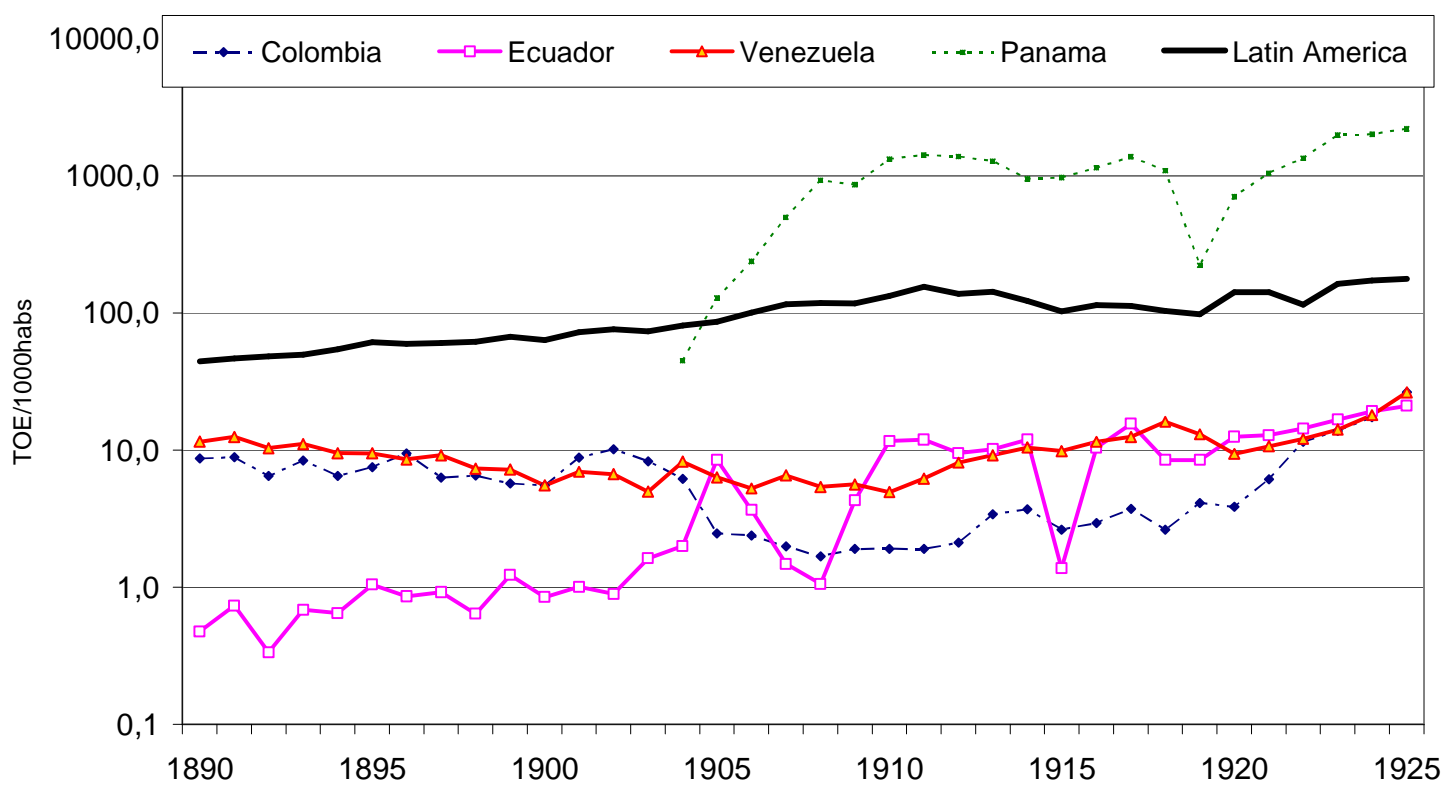

Source: Appendix of data sources

Figure 6

Tonnes of oil equivalent per 1000 habitants by country (Costa Rica, El Salvador, Guatemala, Honduras and Nicaragua)

Costa Rica, El Salvador, Guatemala, Honduras \& Nicaragua, 1890-1925

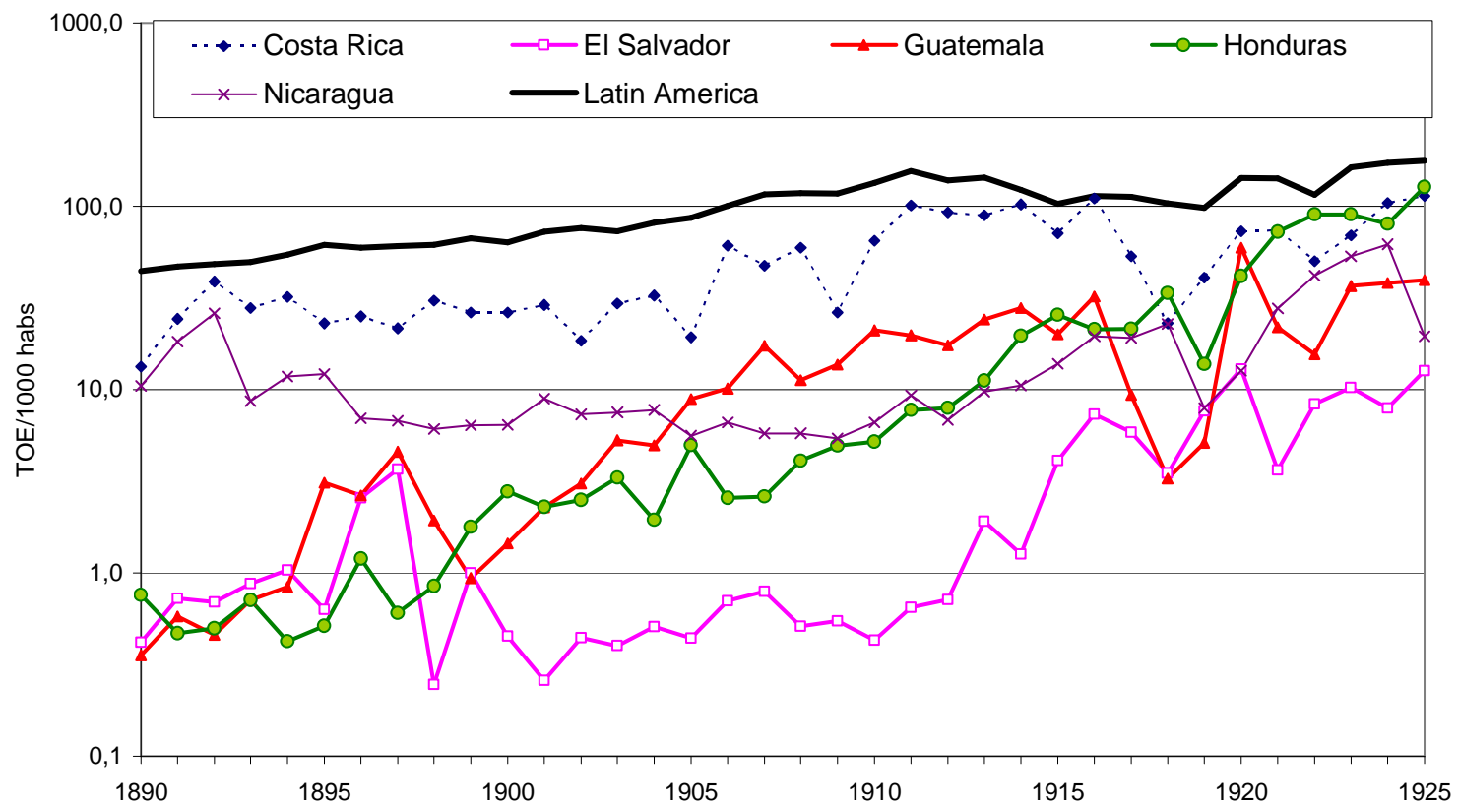

Source: Appendix of data sources 
Figure 7

Tonnes of oil equivalent per 1000 habitants by country (Dominican Republic, Haiti and Jamaica)

Dominican Republic, Haiti \& Jamaica, 1890-1925

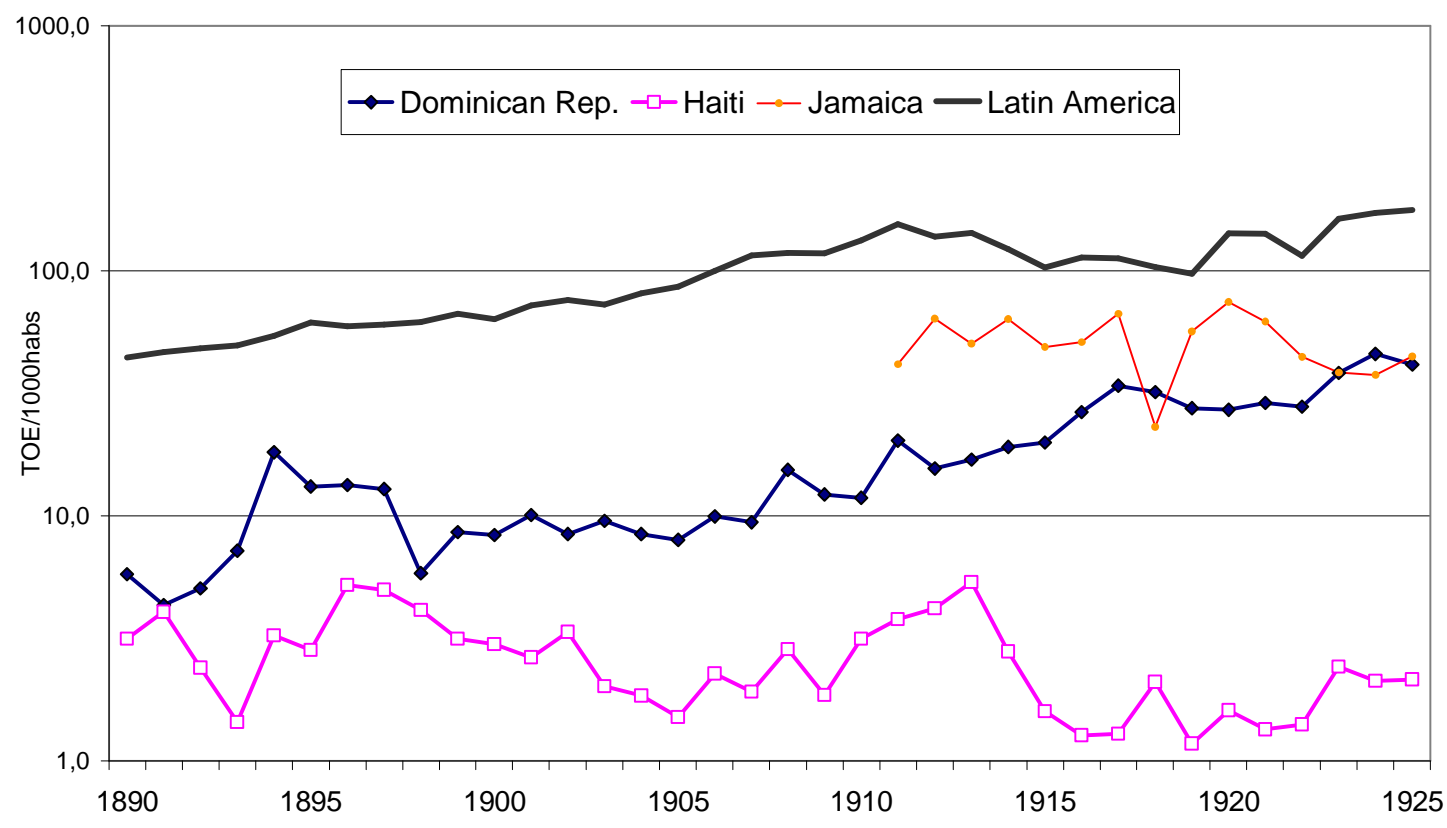

Figure 8

Tonnes of oil equivalent per 1000 habitants by country (Br.Guiana, Br. Honduras, D.Guiana, Fr.Guiana, Fr.W.I.I.)

British Guiana, British Honduras, Dutch Guiana, French Guiana \& French W.I., 1890-1925

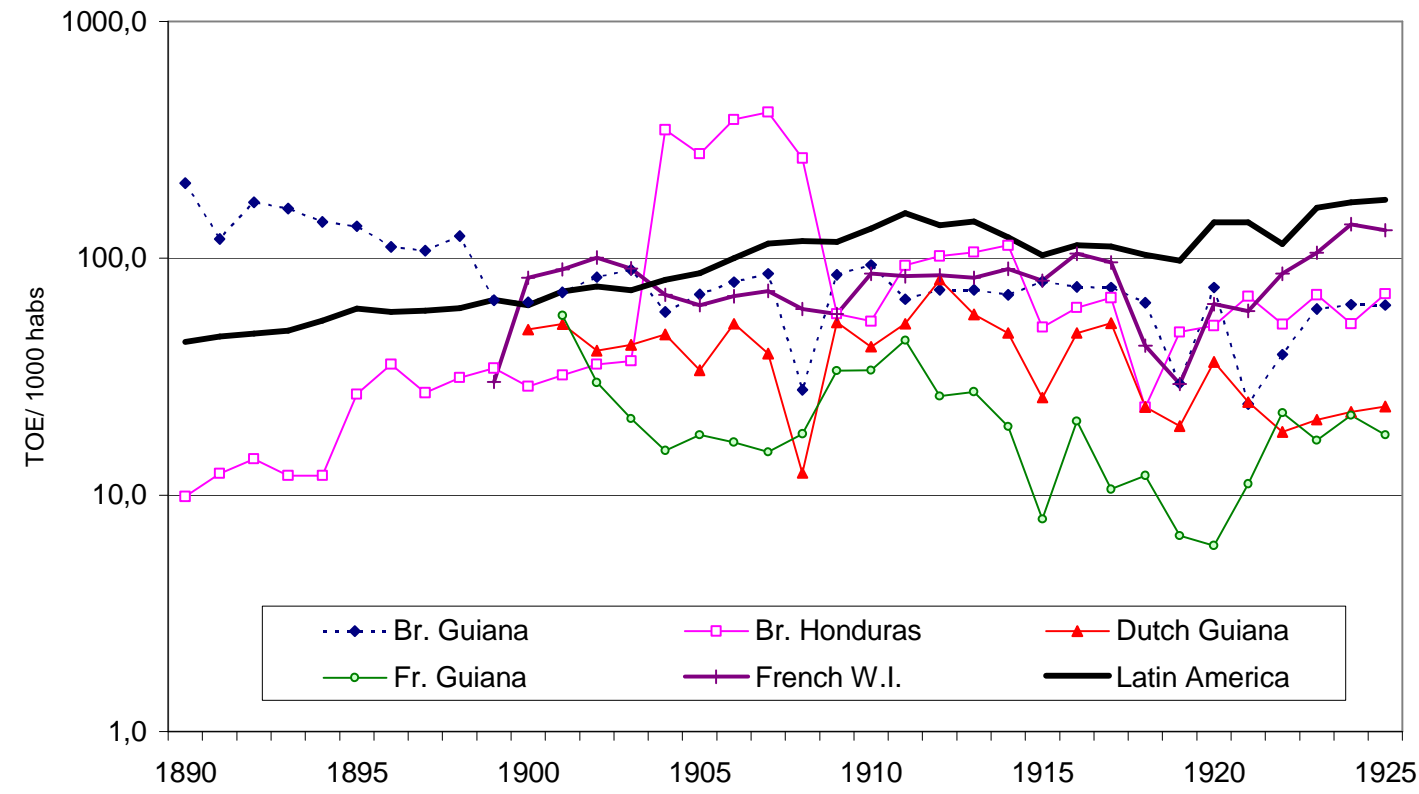

Source: Appendix of data sources 
Figure 9

Tonnes of oil equivalent per 1000 habitants by country (Br.Guiana, Br. Honduras, D.Guiana, Fr.Guiana, Fr.W.I.I.)

Barbados, Bermuda, Danish W.I, Dutch W.I. \& Trinidad-Tobago, 1890-1925

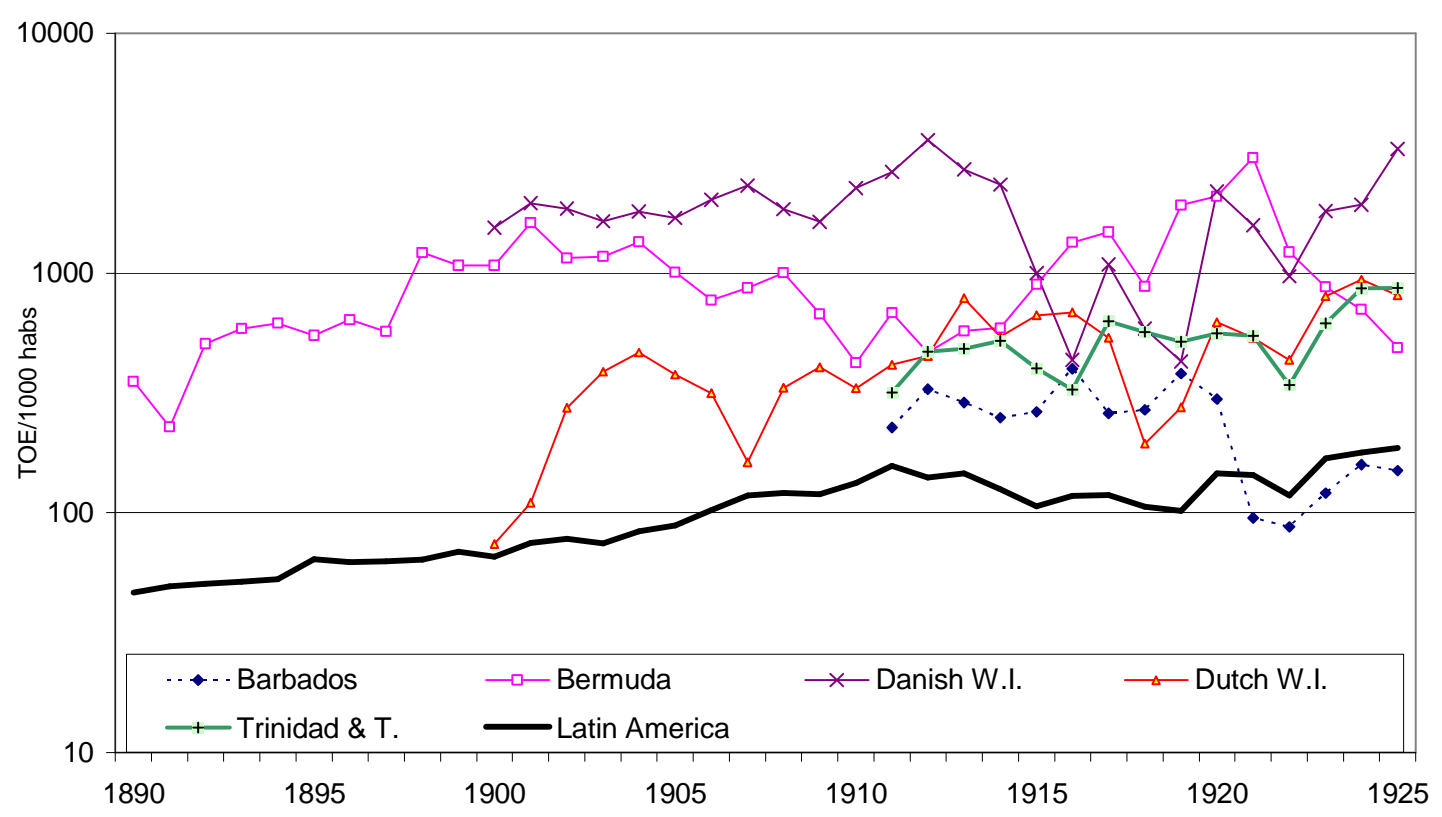

Source: Appendix of data sources 
Figure 10: Energy consumption (toe) and railroads $(\mathrm{km})$ per capita in 1890

TOE-M \& Railroads per capita 1890

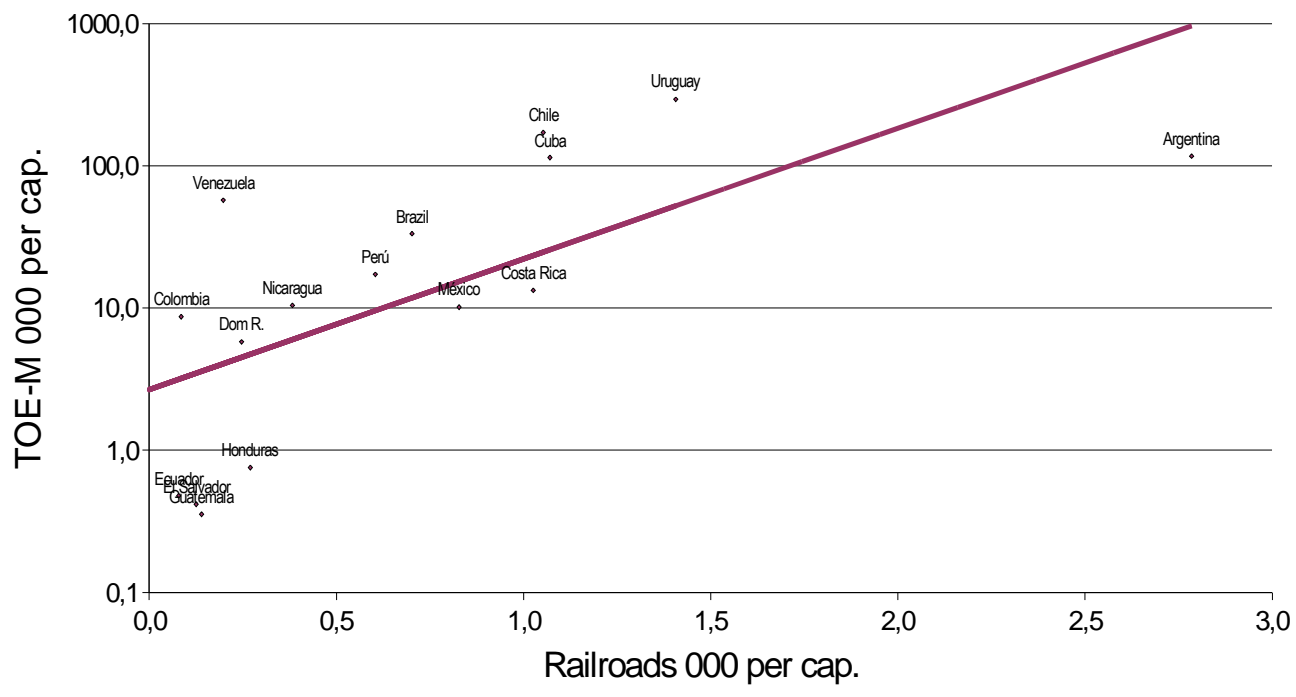

Notes and sources: Actually per 1000 habitants in both cases. Railways from Mitchell (2003), energy as in the end of this paper. 